Tatiane Soares de Lima

\title{
Caracterização das ações do veneno de \\ Crotalus durissus terrificus sobre funções de neutrófilos
}

São Paulo

2010 


\section{Tatiane Soares de Lima}

\section{Caracterização das ações do veneno de \\ Crotalus durissus terrificus sobre funções de neutrófilos}

Dissertação apresentada ao Instituto de Biociências da Universidade de São Paulo para a obtenção do Título de Mestre em Ciências, na Área de Fisiologia Geral.

Orientadora: Dra. Maria Cristina Cirillo

São Paulo 
Lima, Tatiane

Caracterização das ações do veneno de Crotalus durissus terrificus sobre funções de neutrófilos.

$101 \mathrm{p}$.

Dissertação (Mestrado) - Instituto de Biociências da Universidade de São Paulo. Departamento de Fisiologia Geral.

1. Crotalus durissus terrificus. 2. Neutrófilos. 3. Fagocitose. I. Universidade de São Paulo. Instituto de Biociências. Departamento de Fisiologia Geral.

\section{Comissão Julgadora:}

Prof(a). Dr(a)

Prof(a). Dr(a)

Profa. Dra. Maria Cristina Cirillo

Orientadora 
À minha mãe e ao Fábio, pelo amor e confiança que depositam em mim e por serem essenciais em minha vida. 
"Aprender é a única coisa de que a mente nunca se cansa, nunca tem medo e nunca se arrepende."

Leonardo da Vinci 


\section{Agradeço...}

A Deus, por esta oportunidade de vida e trabalho e por iluminar constantemente o meu caminho.

À Dra. Maria Cristina Cirillo, pela dedicação e competência com que orientou este trabalho, por confiar em mim e pela verdadeira amizade que construímos ao longo desses anos. Obrigada Cris!

À Dra. Ida Sano Martins e ao Dr. Luis Roberto C. Gonçalves, pela oportunidade de desenvolver este trabalho no Laboratório de Fisiopatologia.

À Dra. Sandra Coccuzzo Sampaio Vessoni, pela amizade e a importante colaboração ao longo do desenvolvimento deste trabalho.

A Dra. Maísa Splendore Della Casa, pelo fornecimento da fração crotoxina.

Ao técnico Alexander Seixas de Souza, pela ajuda nas análises em microscopia confocal.

À Sol, pela ajuda e a companhia nos looongos experimentos de quinta, sexta, seja lá que dia for... Obrigada pela amizade!

Aos pesquisadores, Marcelo, Ida, Luís, Renata, Anita e Diva, por me receberam com tanto carinho no laboratório e pela ajuda em diversos momentos durante a realização deste trabalho.

Aos alunos do lab, Pri, Edi, Karla, Márcio, Thi, Bianca, Fê, Sâmela, Karina, Luana, Andressa, Sabrina, Karine, André, Odi, Karen, Felipe, Natasha, Lorraine e Rodrigo. Obrigada pela amizade pessoal!

A todos os funcionários do Laboratório de Fisiopatologia. 
À CAPES e à FAPESP, pelo importante apoio financeiro.

A todos os animais utilizados neste trabalho; sem eles nada disso teria sido possível.

À minha mãe, minha grande amiga. Obrigada por todo o amor e a dedicação; obrigada por ser minha companheira, sempre; e obrigada pelo incentivo e o respeito ao meu trabalho. Te amo mãe!

À minha avó Wanda, por todo o amor que sempre dedicou a mim. Você estará sempre em meu coração. Saudade...

Ao Fábio, meu amor... Obrigada por me amar e por confiar em mim. Obrigada pela paciência nos momentos finais desta dissertação. E obrigada pela cumplicidade que existe entre nós... Te amo! 


\section{Índice}

I. INTRODUÇÃO.......................................................................................................... 13

1. Envenenamentos por Serpentes Crotalus durissus terrificus ................................... 13

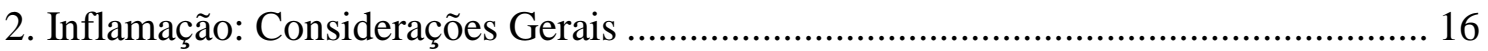

3. Características e Funções dos Neutrófilos ................................................................... 19

4. Vias de Sinalização Envolvidas nas Atividades Fagocítica e Microbicida de

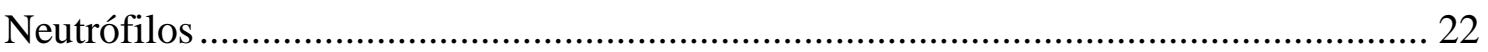

5. Veneno de Crotalus durissus terrificus e a Resposta Inflamatória ............................ 25

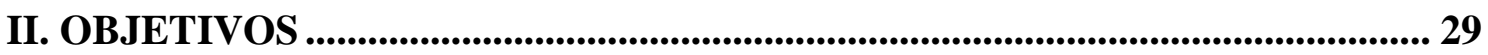

III. MATERIAIS E MÉTODOS .......................................................................... 31

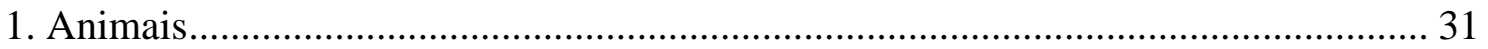

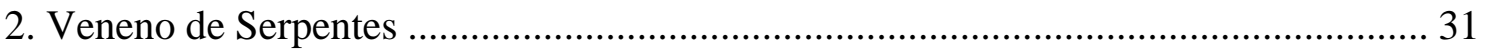

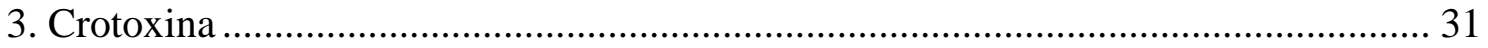

4. Obtenção dos Neutrófilos pelo Modelo de Peritonite ................................................ 32

5. Atividade Fagocítica de Neutrófilos Mediada por Receptores para Fragmentos do Sistema Complemento (C3b/C3bi) ............................................................................. 32

5.1. Opsonização das Partículas de Zimosan com Soro Homólogo .................................... 33

6. Ensaios Imunocitoquímicos para Análise da Fosforilação de Resíduos de Tirosina e

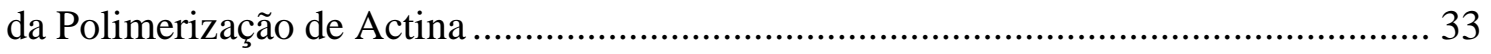

7. Atividade Microbicida de Neutrófilos (Capacidade Fungicida)................................ 35

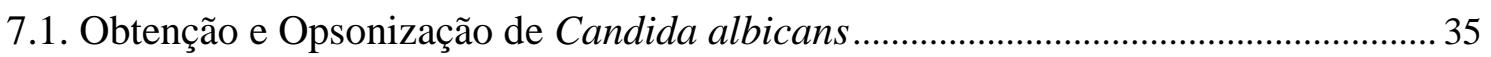

8. Produção de Espécies Reativas do Oxigênio por Neutrófilos ...................................... 36

8.1. Atividade da Enzima NADPH Oxidase - Produção de Ânion Superóxido por

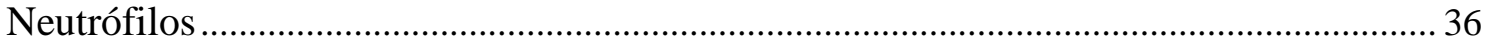

8.2. Produção de Peróxido de Hidrogênio por Neutrófilos ...................................................... 37

8.3. Produção de Ácido Hipocloroso por Neutrófilos …………............................................ 37

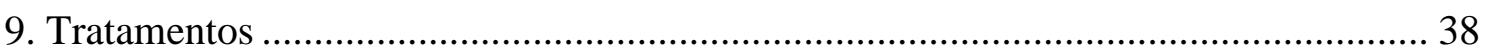


9.1. Efeito in vitro da Crotoxina (Pico II) e dos demais Picos (I e III) sobre a Atividade

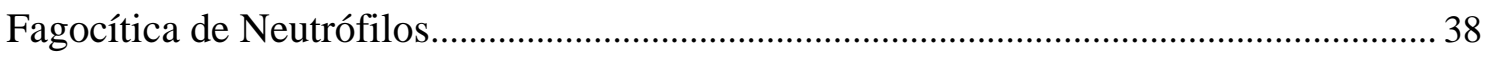

9.2. Efeito in vivo da Crotoxina sobre a Atividade Fagocítica de Neutrófilos 39

9.3. Efeito in vitro e in vivo do VCdt e da Crotoxina sobre a Fosforilação de Resíduos de Tirosina e a Polimerização de Actina

9.4. Efeito in vitro e in vivo do VCdt e da Crotoxina sobre a Atividade Microbicida de Candida albicans por Neutrófilos 40

9.5. Efeito in vitro e in vivo do VCdt e da CTX sobre a Produção de Espécies Reativas do Oxigênio por Neutrófilos

1. Efeito in vitro da Crotoxina (Pico II) e dos demais Picos (I e III) sobre a Atividade Fagocítica de Neutrófilos Mediada por Receptores para Fragmentos do Sistema Complemento (C3b/C3bi)

2. Efeito in vivo da Crotoxina sobre a Atividade Fagocítica de Neutrófilos Mediada por Receptores para Fragmentos do Sistema Complemento (C3b/C3bi).

3. Efeito in vitro e in vivo do VCdt e da Crotoxina sobre a Fosforilação de Resíduos de Tirosina e a Polimerização de Actina 48

4. Efeito in vitro e in vivo do VCdt e da Crotoxina sobre a Atividade Microbicida de Candida albicans por Neutrófilos 56

5. Efeito in vitro e in vivo do VCdt e da Crotoxina sobre a Atividade da Enzima NADPH Oxidase em Neutrófilos

6. Efeito in vitro e in vivo do VCdt e da Crotoxina sobre a Produção de Peróxido de Hidrogênio por Neutrófilos

7. Efeito in vitro e in vivo do VCdt e da Crotoxina sobre a Produção de Ácido Hipocloroso por Neutrófilos

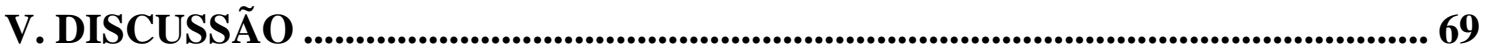

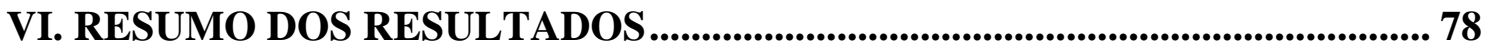

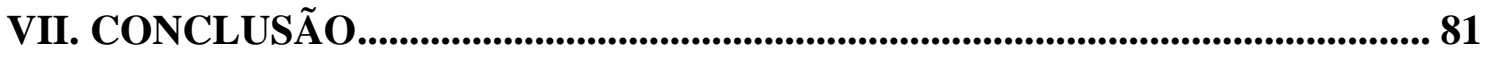

VIII. RESUMO …......................................................................................................................... 83

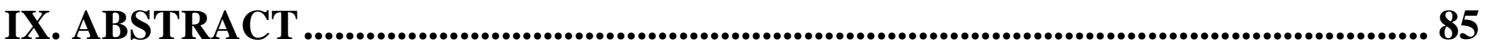

X. REFERÊNCIAS BIBLIOGRÁFICAS ...................................................................... 87 


\section{Lista de Abreviações}

CR1: Complement receptor 1

CR3: Complement receptor 3, CD11b/CD18

CTX: Crotoxina

DAPI: 4', 6'-diamidini-2-fenilindol

EPM: Erro padrão da média

fMLP: Formyl-Methionyl-Leucyl-Phenylalanine

FPR2/ALX: Receptor formil peptídeo 2

GAPs: GTPases-activating proteins

GDIs: Guanine nucleotide dissociation inhibitors

GEFs: Guanine nucleotide exchange factors

GDP: Guanosina difosfato

GTP: Guanosina trifosfato

$\mathbf{H}_{2} \mathbf{O}_{2}$ : Peróxido de hidrogênio

HOCl: Ácido hipocloroso

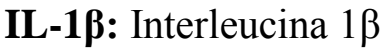

MCP-1: Macrophage inflammatory protein-1

MPO: Mieloperoxidase

NADPH oxidase: Nicotinamide adenine dinucleotide phosphate-oxidase

$\mathbf{O}_{2}^{-}:$Ânion superóxido

PB: Tampão fosfato

PBS: Tampão fosfato salina

PMA: Phorbol 12-myristate 13-acetate

SOD: Superóxido dismutase 
Syk: Spleen tyrosine kinase

TMB: Tetrametilbenzidina

TNF- $\alpha$ : Fator de necrose tumoral

VCdt: Veneno de Crotalus durissus terrificus 


\section{Introdução}




\section{INTRODUÇÃO}

\section{Envenenamentos por Serpentes Crotalus durissus terrificus}

No Brasil, são notificados cerca de 25.000 acidentes ofídicos por ano (SINAN, 2008). As serpentes do gênero Bothrops são as de maior importância médica, sendo estas responsáveis por $90,5 \%$ dos acidentes. As serpentes peçonhentas dos gêneros Crotalus, Lachesis e Micrurus são responsáveis por respectivamente 7,7\%, 1,4\% e 0,4\% dos acidentes ofídicos ocorridos no Brasil (Araújo et al., 2003; SINAN, 2008).

As serpentes do gênero Crotalus, popularmente conhecidas como cascavéis, são terrestres, robustas e pouco ágeis. Uma característica bastante marcante é a presença do chocalho ou guizo na extremidade caudal. O corpo destas serpentes apresenta um colorido de fundo castanho-claro sobre o qual existe uma fileira de manchas dorsais losangulares marrons e marginadas de branco ou amarelo (Melgarejo, 2003).

No Brasil, é encontrada apenas uma espécie de serpente do gênero Crotalus, a Crotalus durissus. Esta espécie tem ampla distribuição geográfica; habita os cerrados do Brasil Central, as regiões áridas e semi-áridas do Nordeste e os campos e áreas abertas do Sul, Sudeste e Norte. Esta espécie compreende cinco subespécies, sendo a Crotalus durissus terrificus a predominante nas regiões Sudeste e Sul (Figura 1). As demais subespécies são a Crotalus durissus cascavella que habita caatingas; a Crotalus durissus collilineatus que está distribuída pelos estados de São Paulo, Mato Grosso, Minas Gerais, Distrito Federal e Goiás; a Crotalus durissus ruruima que é típica das regiões savanas de Roraima e a Crotalus durissus marajoensis que é encontrada na Ilha de Marajó no Pará (Melgarejo, 2003). 


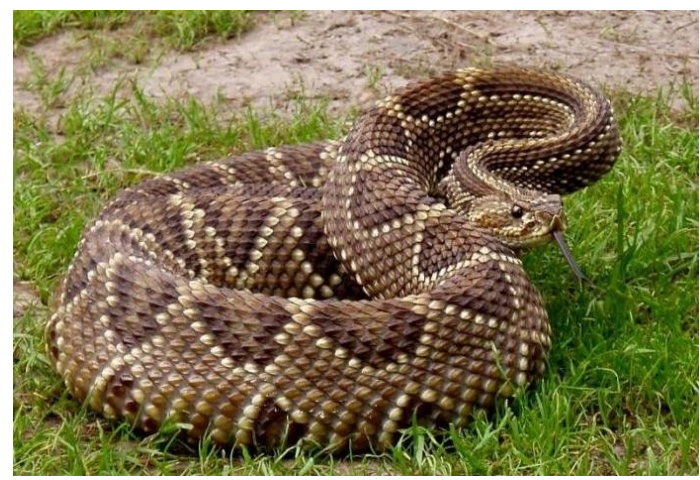

Figura 1. Serpente Crotalus durissus terrificus.

O veneno da serpente Crotalus durissus terrificus (VCdt) contém uma grande quantidade de proteínas e polipeptídios capazes de interferir em uma série de processos fisiológicos (Azevedo-Marques et al., 2003). As principais toxinas presentes neste veneno incluem a crotoxina (CTX), a crotamina, a convulxina e a giroxina (Slotta \& Fraenkel-Conrat, 1938; Moura-Gonçalves \& Vieira, 1950; Barrio, 1961; PradoFranceschi \& Vital-Brazil, 1981).

A crotoxina é o principal componente tóxico do veneno, representa cerca de $60 \%$ do veneno total, sendo responsável por sua elevada toxicidade (Slotta \& FraenkelConrat, 1938; Vital-Brazil, 1972). Esta toxina foi isolada por Slotta e Fraenkel-Conrat, em 1938, e sua estrutura foi descrita por Fraenkel-Conrat e Singer, em 1956. A crotoxina é uma $\beta$-neurotoxina heterodimérica formada pela associação não covalente de duas subunidades: a fosfolipase $\mathrm{A}_{2}$ (componente $\mathrm{B}, \mathrm{CB}$ ), uma proteína básica com atividade fosfolipásica e baixa toxicidade, e a crotapotina (componente A, CA), uma proteína ácida desprovida de atividade enzimática ou tóxica, que atua como carreadora da fosfolipase $A_{2}$, potencializando sua atividade letal ao mesmo tempo em que diminui sua atividade enzimática dentro do complexo crotoxina (Habermann \& Breithaupt, 1978; Bon et al., 1979; Choumet et al., 1996; Sampaio et al., 2010). 
O veneno da serpente Crotalus durissus terrificus apresenta atividades neurotóxica, miotóxica e coagulante (Nahas et al., 1964; Rosenfeld, 1971; AzevedoMarques et al., 1987; Cupo et al., 1988). A atividade neurotóxica do veneno é a responsável pelo quadro de paralisia dos músculos esqueléticos (fácies neurotóxica), ptose palpebral, diminuição da motricidade ocular e da acuidade visual e insuficiência respiratória (Rosenfeld, 1971; Amaral et al., 1991). Esta atividade é atribuída à crotoxina, que atua sobre o sistema nervoso periférico, bloqueando a transmissão na junção neuromuscular e inibindo a liberação de acetilcolina, um importante neurotransmissor (Vital-Brazil \& Excell, 1971; Hawgood \& Santa de Sá, 1979). Quando em altas concentrações, a crotoxina também atua na membrana pós-sináptica, dessensibilizando os receptores para acetilcolina (Bon et al., 1979).

O efeito miotóxico do veneno decorre da ação da crotoxina e da crotamina, uma proteína básica de baixo peso molecular, sem atividade enzimática e que corresponde a cerca de $17 \%$ do veneno total (Ownby et al., 1976; Gopalakrishnakone et al., 1984).

A ação coagulante do veneno é atribuída a um componente tipo trombina (thrombin-like), a giroxina, que converte o fibrinogênio em fibrina e assim aumenta o tempo de coagulação do sangue (Sano-Martins et al., 2001).

Assim sendo, o quadro de envenenamento humano por Crotalus durisssus terrificus caracteriza-se por manifestações sistêmicas, tais como: mal estar, prostração, sudorese, vômitos, sonolência ou inquietação, que são observadas nas primeiras horas após o acidente. Além disso, devido à atividade miotóxica do veneno, os pacientes acidentados por Crotalus durissus terrificus apresentam quadro de rabdomiólise generalizada (Azevedo-Marques, 1985; Magalhães et al., 1986; Jorge \& Ribeiro, 1992). Outra manifestação sistêmica importante é a incoagulabilidade sangüínea observada em cerca de 50\% dos acidentes crotálicos, em humanos (Jorge \& Ribeiro, 1992; Sano- 
Martins et al., 2001), e também verificada experimentalmente em cães, que apresentam hipofibrinogenemia e ativação secundária do sistema fibrinolítico (Sousa-e-Silva et al., 2003).

Apesar dessas manifestações sistêmicas, nos envenenamentos humanos e experimentais, não se observam reações inflamatórias significativas no local da picada (Amorim et al., 1951; Rosenfeld, 1971).

\section{Inflamação: Considerações Gerais}

A resposta inflamatória é uma resposta do organismo à injúria que ocorre no tecido conjuntivo vascularizado. Essa resposta, independente da natureza do estimulo lesivo, é caracterizada por eventos vasculares, celulares e linfáticos, que se desenvolvem com a finalidade de eliminar o agente lesivo, restituir o tecido lesado e manter a homeostasia do organismo (Kumar et al., 2005). As manifestações uniformes que caracterizam a resposta inflamatória são decorrentes da ação de mediadores químicos, liberados após o estímulo lesivo que atuam de maneira inter-relacionada em todos os eventos da resposta inflamatória (Rocha e Silva \& Garcia-Leme, 1972; Ferreira \& Vane, 1973; Majno \& Joris, 2004). Esses mediadores podem ser originados do plasma, tais como os componentes do sistema complemento, do sistema de coagulação e as cininas ou ainda originados de células e de tecidos, tais como a histamina, a serotonina, os metabólitos do ácido araquidônico, o fator de ativação plaquetária, o óxido nítrico e as interleucinas (Rankin, 2004; Majno \& Joris, 2004, Kumar et al., 2005).

Particularmente, os metabólitos do ácido aracdônico são gerados por ação da enzima fosfolipase $A_{2}$, a qual degrada os fosfolipídios de membrana celular e assim libera o ácido aracdônico; este por sua vez, é degradado pela ação das enzimas ciclooxigenases e lipoxigenases (Crowley, 1996). As prostaglandinas, as prostaciclinas 
e os tromboxanos são os metabólitos gerados pela via das ciclooxigenases, enquanto que os leucotrienos e as lipoxinas são gerados pela via das lipoxigenases (Rankin, 2004). Sobre a atuação desses metabólitos na resposta inflamatória, as prostaglandinas e as prostaciclinas causam vasodilatação e potencializam a formação do edema inflamatório (Majno \& Joris, 2004), enquanto que os leucotrienos causam vasoconstrição, aumento da permeabilidade vascular e atuam como agentes quimiotáticos (Lewis et al., 1990). Com relação às lipoxinas, estas são geradas pela ação das enzimas 12-lipoxigenase de plaquetas ou 15-lipoxigenase de macrófagos; são mediadores que possuem atividade antiinflamatória e assim participam da resolução da resposta inflamatória (Serhan \& Sheppard, 1990; Levy et al., 1993; Bonnans et al., 2002). A lipoxina $A_{4}$ inibe a migração de neutrófilos e a liberação da interleucina $1 \beta$ (IL-1ß) por essas células (Godson et al., 2000). Ainda, as lipoxinas estimulam a fagocitose de neutrófilos apoptóticos por macrófagos (Godson et al., 2000), porém inibem a fagocitose por neutrófilos, uma vez que reduzem a expressão de seus receptores CR3 (complement receptor 3) (Maderna \& Godson, 2009).

Os eventos vasculares da resposta inflamatória compreendem alterações hemodinâdimicas, que culminam com o extravasamento de proteínas plasmáticas para o tecido adjacente. Imediatamente após o estimulo lesivo, ocorre uma vasoconstrição transitória seguida de uma vasodilatação observada, principalmente, nas vênulas póscapilares. Essas alterações são seguidas por mudanças estruturais na parede do vaso caracterizadas, principalmente, pela contração da célula endotelial e abertura de junções entre essas células. Essas aberturas levam ao aumento da permeabilidade vascular e consequente extravasamento de proteínas plasmáticas para o tecido intersticial (KowalVern et al., 1997; Rankin, 2004), o que caracteriza o edema inflamatório (Janeway \& Travers, 1994; Vane, 1994; Blake \& Ridker, 2001; Tedgui \& Mallat, 2001). Ainda, em 
consequência ao extravasamento plasmático ocorre o aumento da viscosidade sanguínea e a redução do fluxo sanguíneo. Essas alterações hemodinâmicas levam à estase sanguínea, marginação leucocitária e migração destas células para o tecido extravascular (Kumar et al., 2005). O processo de migração transendotelial dos leucócitos pode ocorrer através das junções das células endoteliais adjacentes (via para celular) ou ainda, em alguns casos, através do corpo celular (via transcelular) (Engelhard \& Wolburg, 2004; Carman \& Springer, 2004).

O recrutamento de células para o foco inflamatório é um fenômeno fundamental na resposta inflamatória que envolve a interação específica e a consequente sinalização bidirecional entre as células endoteliais e os leucócitos. Essa interação é mediada por moléculas de adesão e pela liberação de mediadores inflamatórios, tais como: citocinas (IL-1; TNF- $\alpha$, fator de necrose tumoral $\alpha$ ), quimiocinas (MCP-1, macrophage inflammatory protein-1), fragmentos do sistema complemento (C5a) e outros.

O processo de migração transendotelial dos leucócitos ocorre em diferentes fases: inicialmente, os leucócitos rolam sobre o endotélio, em seguida se aderem firmemente à superfície deste e, migram em direção ao foco inflamatório. Esses eventos são denominados, respectivamente, de rolling, adesão e migração e, envolvem a expressão de moléculas de adesão, entre estas, as selectinas, as integrinas, as imunoglobulinas e os seus ligantes (Springer, 1995; Rankin, 2004). A interação entre essas moléculas de adesão e seus respectivos ligantes, permite que os eventos de rolling, adesão e migração leucocitária ocorram de forma dinâmica no decorrer do processo inflamatório.

A migração direcionada dos leucócitos, denominada de quimiotaxia, é essencial para a resposta inflamatória. Este processo envolve uma variedade de moléculas que atuam como quimiotáticos para os leucócitos, os quais incluem: oligopeptídeos de 
bactérias do tipo formilpeptideo (FMLP; Formyl-Methionyl-Leucyl-Phenylalanine); proteínas desnaturadas, alguns lipídios e lipopolissacarídeos; fragmentos do sistema complemento (C5a e C3a); lipídios bioativos (leucotrieno $\mathrm{B}_{4}$ ); citocinas (interleucina 8) e quimiocinas, tais como MCP-1 (Niggli, 2003; Kumar et al., 2005). Os agentes quimiotáticos se ligam a receptores específicos presentes na superfície dos leucócitos, os quais desencadeiam a ativação de diversas proteínas intracelulares sinalizadoras e a consequente polimerização dos filamentos de actina, formação de pseudópodes e movimento celular direcionado (Niggli, 2003; Simon \& Green, 2005, Kölsch, 2008).

As primeiras células a migrarem para o foco inflamatório são os leucócitos polimorfonucleares, particularmente os neutrófilos (Rankin, 2004; Kumar et al., 2005). O exsudato celular é caracterizado, na fase inicial da resposta inflamatória, pela presença predominante de neutrófilos e, posteriormente, pela predominância de células mononucleares. Uma vez no sítio inflamatório, essas células iniciam o processo de fagocitose do agente lesivo e dos debris celulares (Auger \& Ross, 1992).

\section{Características e Funções dos Neutrófilos}

Os neutrófilos são células sanguíneas que se originam na medula óssea a partir de uma célula precursora hematopoética, denominada de stem cell. Esta célula divide-se e, posteriormente, por processos de diferenciação e de maturação, se transforma sequencialmente em: mieloblasto, promielócito, mielócito, metamielócito, neutrófilo bastonete e neutrófilo segmentado. Este último, ainda no interior da medula, sofre a completa diferenciação, e a seguir passa para o sangue periférico (Laszlo \& Rundles, 1972).

Os neutrófilos segmentados são células arredondadas com 10 a $14 \mu \mathrm{m}$ de diâmetro, possuem núcleo lobulado com dois a cinco lóbulos ligados por pontes de 
cromatina e não possuem nucléolos (Laszlo \& Rundles, 1972). No citoplasma dos neutrófilos são encontrados grânulos e vesículas que funcionam como reservatórios para proteínas com ação microbicida, bem como para receptores de moléculas de adesão, proteínas da matriz extracelular, produtos bacterianos e mediadores inflamatórios solúveis (Bertino \& Silber, 1972; Faurschou \& Borregaard, 2003).

Três tipos de grânulos diferentes são encontrados no citoplasma de neutrófilos: os azurófilos ou primários, os secundários e os terciários. Os grânulos azurófilos formam-se nos promielócitos e são ricos em mieloperoxidase (MPO), uma hemoproteína envolvida na atividade microbicida dos neutrófilos. Ainda, outros componentes com atividade microbicida estão presentes nesses grânulos: alfadefensinas (Ganz et al., 1985; Daher et al., 1986; Lehrer et al., 1988); proteínas bactericidas de permeabilidade aumentada e proteases, tais como, a proteinase- 3 , a catepsina G, a elastase, entre outras (Iovine et al.. 1997, Campanelli et al., 1990; Faurschou \& Borregaard, 2003, Kumar et al., 2005).

Os grânulos específicos secundários e terciários são formados a partir do estágio de mielócito e não possuem a enzima MPO, porém possuem substâncias microbicidas, tais como a lactoferrina e a lisozima, além de importantes metaloproteases: a colagenase, a gelatinase e a leucosidina (Mollinedo et al., 1991; Borregaard et al., 1993, Kumar et al., 2005).

Os neutrófilos desempenham papel fundamental no mecanismo de defesa do hospedeiro. Como citado anteriormente, são as primeiras células a migrarem para o foco inflamatório e as suas principais funções na inflamação são a fagocitose e a secreção de substâncias que atuam na degradação do agente lesivo (Ishibashi \& Yamashita, 1982).

A fagocitose é um processo dinâmico desencadeado após a interação do substrato com o fagócito, essa interação é facilitada pela presença de opsoninas 
(imunoglobulinas e fatores do complemento), as quais se ligam aos seus receptores específicos presentes na membrana desses fagócitos (Berger et al., 1988; Neuman et al., 1990). Dentre estes receptores estão, o Fc $\gamma$ que reconhece o fragmento Fc da IgG, e os os receptores CR1 (complement receptor 1) e CR3, os quais interagem, respectivamente, com os fragmentos $\mathrm{C} 3 \mathrm{~b}$ e $\mathrm{C} 3 \mathrm{bi}$ do complemento (Unkeless \& Wrigt, 1988; Lee et al., 2003).

O processo de fagocitose está associado à liberação de proteínas microbicidas contidas nos grânulos citoplasmáticos, bem como ao aumento do metabolismo oxidativo da célula, conhecido como burst respiratório, durante o qual são produzidas espécies reativas do oxigênio, também com potencial microbicida.

A geração de espécies reativas do oxigênio se inicia pela ativação da enzima NADPH oxidase (nicotinamide adenine dinucleotide phosphate-oxidase), presente na membrana plasmática e na membrana do fagossoma. A NADPH oxidase consiste de cinco componentes que são essenciais para a sua atividade, os quais estão distribuídos entre a membrana do fagossoma (flavocitocromo b558, p22+gp91) e o citoplasma da célula (p67, p40 e p47 e a GTPase Rac). Na presença de um estímulo, ocorre a fosforilação de p67, p40 e p47 e a ativação de Rac pela sua ligação a uma guanosina trifosfato (GTP); e a seguir, a translocação desses componentes para a membrana, o que leva a ativação da NADPH oxidase (DeLeo \& Quinn, 1996; Babior et al., 2001; Roos et al., 2003). Essa enzima, por sua vez, catalisa a geração de ânion superóxido $\left(\mathrm{O}_{2}{ }^{-}\right)$, pela transferência de um elétron para uma molécula de $\mathrm{O}_{2}$. O ânion superóxido é convertido, pela ação da enzima superóxido dismutase (SOD), em peróxido de hidrogênio $\left(\mathrm{H}_{2} \mathrm{O}_{2}\right)$, o qual em altas concentrações apresenta atividade microbicida (Imlay \& Linn, 1986). A maior parte do peróxido de hidrogênio reage com a mieloperoxidase, presente nos grânulos azurófilos, formando o complexo MPO- $\mathrm{H}_{2} \mathrm{O}_{2}$. Este complexo, por sua vez, 
reage com os íons cloro formando o ácido hipocloroso $(\mathrm{HOCl})$, principal espécie reativa do oxigênio produzida pelos neutrófilos (Klebanoff, 2005) (Figura 2).

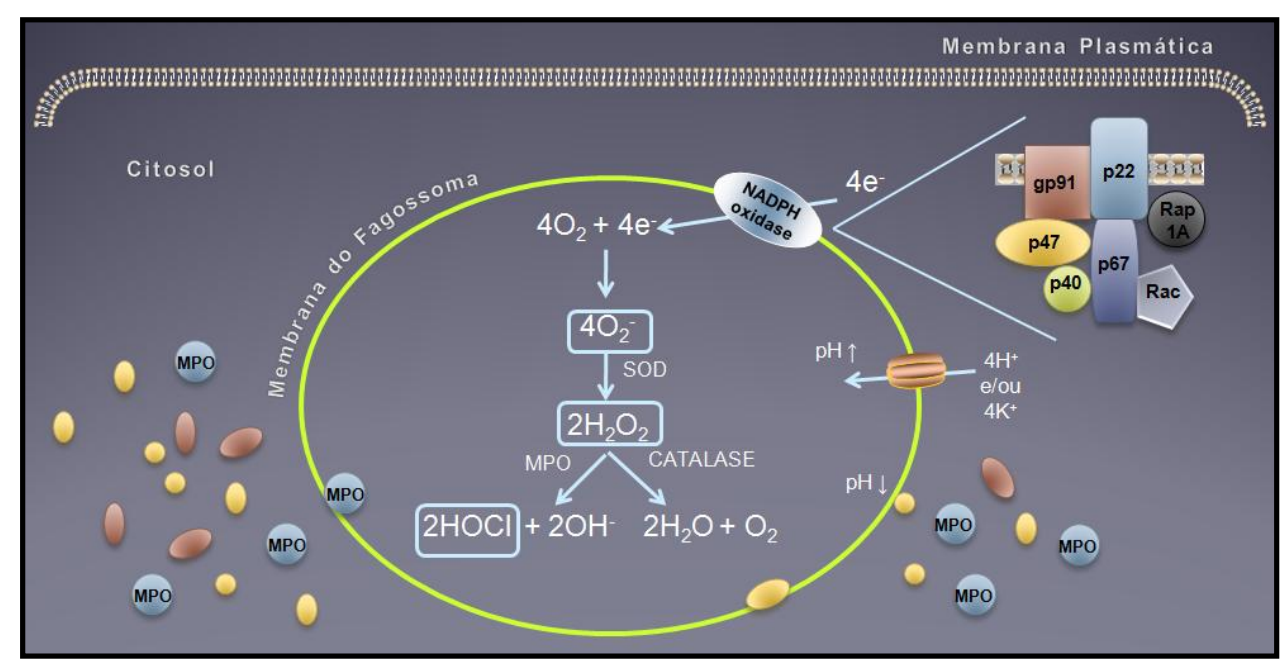

Figura 2. Ativação da enzima NAPH oxidase e consequente geração das espécies reativas do oxigênio por neutrófilos: ânion superóxido $\left(\mathrm{O}^{-}\right)$, peróxido de hidrogênio $\left(\mathrm{H}_{2} \mathrm{O}_{2}\right)$ e ácido hipocloroso $(\mathrm{HOCl})$.

\section{Vias de Sinalização Envolvidas nas Atividades Fagocítica e Microbicida de}

\section{Neutrófilos}

No processo de fagocitose, após a ligação da partícula ao seu receptor específico, para que a mesma seja englobada e o processo de fagocitose se complete, é necessária a reorganização do citoesqueleto da célula, com a polimerização localizada dos filamentos de actina. Alguns estudos comprovam esse fato pela utilização de drogas, como por exemplo, a citocalasina, que bloqueia a formação de F-actina (actina polimerizada) e inibe o processo de fagocitose (Zigmond \& Hirsch, 1972; Axline \& Reaven, 1974; Maniak et al., 1995).

A dinâmica de polimerização dos filamentos de actina na célula é regulada por vias de sinalização intracelular desencadeadas após a ativação do receptor envolvido na 
fagocitose (Groves et al., 2008). Ao longo desta cascata de sinalização, ocorre a fosforilação de resíduos de tirosina, serina ou treonina de diversas proteínas, as quais são ativadas e passam a desempenhar suas funções como sinalizadoras ou efetoras do processo de reorganização do citoesqueleto (Walzog et al., 1996; Kwiatkowska \& Sobota, 1999). A proteína tirosina quinase Syk (spleen tyrosine kinase) é um exemplo de proteína sinalizadora envolvida no processo de fagocitose por neutrófilos, mediado por receptores CR3 (Shi et al., 2006) ou Fc (Rivas-Fuentes et al., 2010).

Ainda, em relação às proteínas sinalizadoras, a literatura tem demonstrado o papel fundamental das pequenas GTPases da família Rho, tais como a Rho, a Rac e a Cdc42, na regulação da polimerização dos filamentos de actina (Tapon \& Hall, 1997). Essas pequenas GTPases são ativadas quando se ligam a GTP, entretanto tornam-se inativas quando hidrolizam GTP em GDP (guanosina difosfato). A ativação das GTPases é regulada por três classes de proteínas: GEFs (guanine nucleotide exchange factors) que promovem a troca de GDP por GTP; GAPs (GTPases-activating proteins) que aceleram a hidrólise de GTP em GDP e GDIs (guanine nucleotide dissociation inhibitors) que inibem a troca de GDP por GTP (Schmitz et al., 2000; Fenteany \& Glogauer, 2004).

As GTPases Rac e Cdc42 são essenciais para o processo de fagocitose mediado por receptores Fc $($ Massol et al., 1998; Caron \& Hall, 1998), enquanto que a GTPase Rho tem papel significante na fagocitose mediada por receptores CR3 (CD11b/CD218) (Caron \& Hall, 1998; Le Cabec et al., 2002; Chimini \& Chavrier, 2000). Ainda, na fagocitose mediada por receptores CR3, é importante mencionar que a proteína tirosina quinase Syk pode ativar GEFs da família Vav, que por sua vez, são essenciais para a ativação de Rho e do complexo multifuncional organizador de actina Arp2/3 (May et al., 2000; Gakidis et al., 2004; Shi et al., 2006) (Figura 3). 


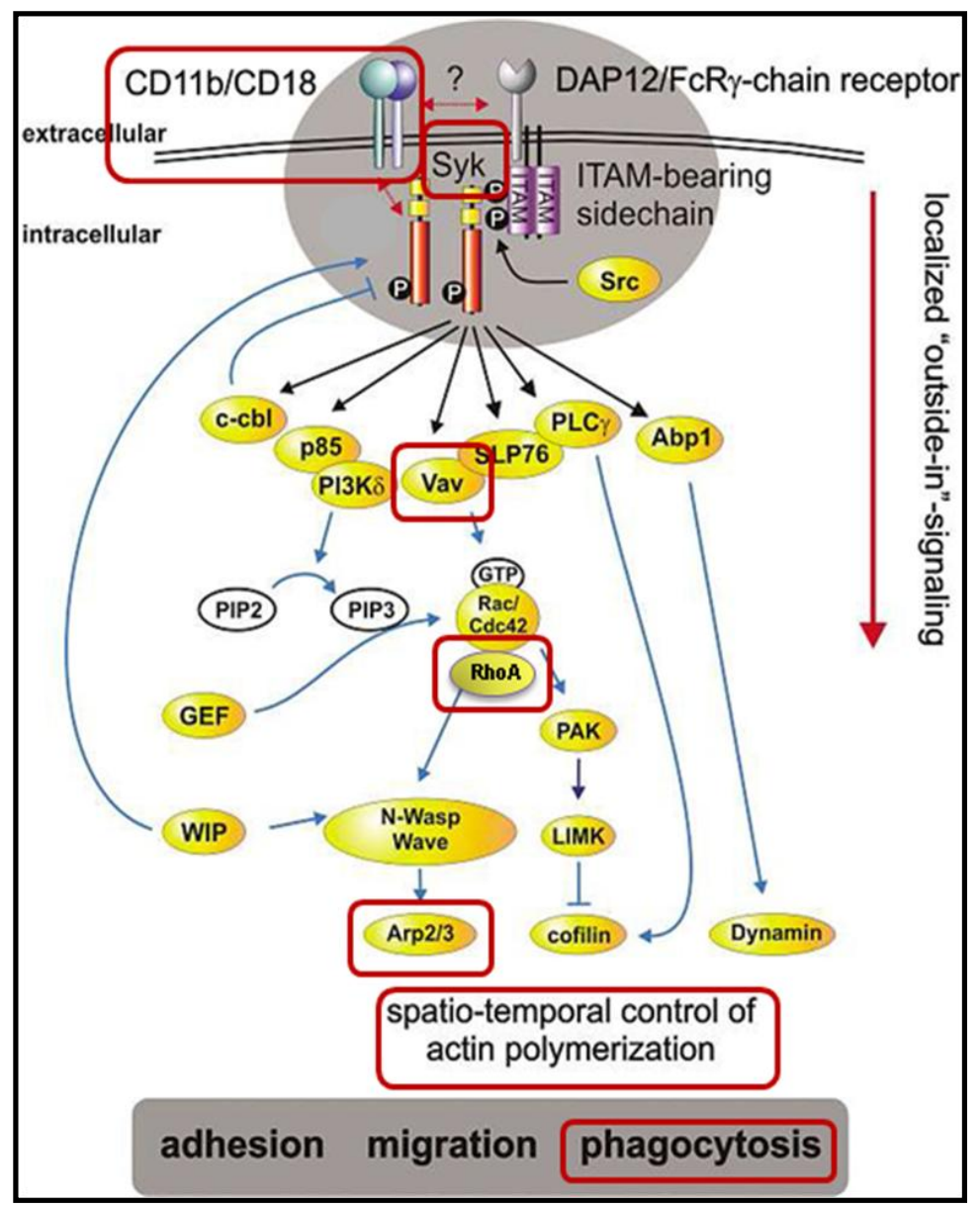

Figura 3. Sinalização intracelular envolvida da fagocitose mediada por receptores CR3 (CD11b/CD18). Após a interação do ligante (C3bi) ao receptor CR3, ocorre a ativação da proteína tirosina quinase Syk, seguida da ativação de Vav, RhoA e Arp 2/3 para a polimerização de actina e o englobamento da partícula. Fonte: Schymeinsky et al., 2007, modificado.

Em relação à sinalização envolvida na atividade microbicida dos neutrófilos, a ativação da enzima NADPH oxidase depende da GTPase Rac2, independente do tipo de receptor pelo qual o processo de fagocitose se inicia (Kim \& Dinauer, 2001; Werner, 2004). Além disso, Abdel-Latif e col. (2005) demonstraram o papel significante da Rac2 para a liberação de substâncias contidas nos grânulos primários de neutrófilos, tais como a elastase e a MPO. Adicionalmente, Koh e col. (2005), utilizando animais 
knockout para Rac1, demonstraram a participação dessa proteína na atividade microbicida.

\section{Veneno de Crotalus durissus terrificus e a Resposta Inflamatória}

O veneno de Crotalus durissus terrificus (VCdt) tem fraca atividade inflamatória e desencadeia, no local da inoculação, uma resposta inflamatória caracterizada por discreto acúmulo de leucócitos polimorfonucleares e edema de fraca intensidade, mediado principalmente por histamina (Sousa-e-Silva et al., 1996).

Além da baixa atividade flogística, foi demonstrado que o VCdt ou toxinas isoladas deste veneno são capazes de modular a resposta inflamatória. Assim, Landucci e colaboradores (1995) mostraram que a crotapotina, o componente A da crotoxina (CTX), inibe o edema de pata de ratos induzido por carragenina. Da mesma forma, em camundongos, a injeção de VCdt imediatamente após a administração intraperitoneal de tioglicolato, determina o decréscimo no número de leucócitos que migram para a cavidade peritoneal, além de causar a inibição, in vitro e in vivo, do espraiamento e da fagocitose por macrófagos peritoneais (Sousa-e-Silva et al., 1996), células essenciais na resposta inflamatória.

Em continuidade a esse estudo, Sampaio et al., (2001), avaliando o efeito do VCdt sobre o metabolismo de macrófagos peritoneais de ratos e a possível correlação entre as modificações deste metabolismo com as alterações funcionais destas células, demonstraram dualismo na ação deste veneno, uma vez que foi observada tanto estimulação do burst respiratório (geração de peróxido de oxigênio e óxido nítrico), da atividade fungicida e do metabolismo de glicose e glutamina, quanto a inibição do espraiamento e da atividade fagocítica dessas células. Além disso, foi demonstrado que a CTX, particularmente, a fosfolipase $\mathrm{A}_{2}$, o componente $\mathrm{B}$ desta toxina, é a responsável 
pela ação inibitória do VCdt sobre o processo de fagocitose por macrófagos (Sampaio et al., 2003; 2005). Em relação a essa ação inibitória, Sampaio e col. (2006a) demonstraram que a mesma é modulada, por mediadores químicos gerados na via da lipoxigenase sendo decorrente da drástica diminuição da fosforilação de resíduos de tirosina de proteínas sinalizadoras e da expressão de proteínas GTPases, RhoA e Rac (Sampaio et al., 2006b).

Dando continuidade aos estudos que evidenciam o efeito modulador do VCdt sobre a inflamação, foi demonstrado pelo nosso grupo que o VCdt tem efeito antiinflamatório prolongado sobre a resposta inflamatória induzida pela carragenina, em camundongos. Esse estudo mostrou que uma única dose de VCdt, administrada pela via subcutânea, 7 ou 21 dias antes da injeção de carragenina inibe, respectivamente, o desenvolvimento do edema de pata e a migração celular para a cavidade peritoneal, induzidos por este agente inflamatório. Este efeito antiinflamatório também foi observado após a instalação da resposta inflamatória (Nunes et al., 2007). Além disso, recentemente, Nunes e col. (2010) demonstraram que a crotoxina é o componente responsável pelo efeito antiinflamatório do VCdt e que este efeito envolve a ativação de receptores formil peptídeo.

Ainda, dentro dessa linha de investigação, considerando o papel fundamental dos neutrófilos na resposta inflamatória e a ausência de estudos que determinassem a ação do VCdt sobre essas células, Lima e col. (2007) mostram que, assim como observado para os macrófagos, o VCdt, in vitro e in vivo, inibe a fagocitose mediada por CR1/CR3, por neutrófilos obtidos no modelo de peritonite induzido pela carragenina em ratos. Nesse estudo foi observado também o efeito inibitório prolongado, uma vez que esse efeito permanece por 14 dias após a administração de uma única dose do VCdt (Lima et al., 2007). 
Apesar dessas evidências, ainda não foi investigado qual o componente do VCdt é responsável pela ação inibitória sobre a fagocitose por neutrófilos, bem como quais os possíveis mecanismos envolvidos nessa ação. Além disso, ainda não foi estudado e efeito do VCdt sobre a atividade microbicida e os produtos gerados pelo aumento do metabolismo oxidativo da célula, ações relevantes para o desenvolvimento e a resolução da resposta inflamatória. 


\section{Objetivos}




\section{OBJETIVOS}

Baseado nos dados apresentados, o objetivo geral desse estudo é ampliar a caracterização das ações do VCdt sofre funções de neutrófilos. Para tanto, os objetivos específicos são:

Identificar qual o componente do VCdt é responsável pelo efeito inibitório sobre a fagocitose por neutrófilos;

Investigar o efeito in vitro e in vivo do VCdt e da CTX sobre a fosforilação de resíduos de tirosina e a polimerização de actina durante a fagocitose por neutrófilos;

Avaliar o efeito in vitro e in vivo do VCdt e da CTX sobre a atividade microbicida e a produção de espécies reativas do oxigênio por neutrófilos. 
Materiais e Métodos 


\section{MATERIAIS E MÉTODOS}

\section{Animais}

Foram utilizados ratos Wistar (160-180g) fornecidos pelo Biotério Central do Instituto Butantan e mantidos no Laboratório de Fisiopatologia com livre acesso a água e ração, por um período mínimo de um a dois dias antes de serem utilizados nos experimentos. Os protocolos experimentais que foram realizados neste projeto foram aprovados pela Comissão de Ética do Instituto Butantan (Protocolos 407/07 e 705/10).

\section{Veneno de Serpentes}

Foi utilizado veneno da espécie Crotalus durissus terrificus, liofilizado, extraído de vários exemplares de espécimes adultos, fornecido pelo Laboratório de Herpetologia do Instituto Butantan e estocado a $-20^{\circ} \mathrm{C}$. O veneno foi diluído em salina estéril $0,85 \%$ ou em meio RPMI 1640 no momento da utilização.

\section{Crotoxina}

A purificação da fração CTX do VCdt foi realizada pela pesquisadora Maísa S. Della-Casa do Laboratório de Imunopatologia do Instituto Butantan segundo o método descrito por Rangel-Santos (2004), modificado. Neste processo, são obtidos três picos (I, II e III), sendo o pico II correspondente à eluição da CTX, a qual representa aproxidamente $60 \%$ do VCdt bruto (Slotta \& Fraenkel-Conrat, 1938). Nos picos I e III estão contidas as demais toxinas do VCdt (crotamina, giroxina e convulxina), entretanto a literatura não descreve quais toxinas estão contidas em cada um desses picos. As amostras contendo a CTX foram testadas quanto à homogeneidade por eletroforese em gel de poliacrilamida e a atividade de fosfolipase $A_{2}$ foi analisada em substrato 
cromogênico. Os tubos correspondentes a CTX foram reunidos e dialisados, e a sua concentração foi determinada pelo método de Bradford (1976).

\section{Obtenção dos Neutrófilos pelo Modelo de Peritonite}

Com a finalidade de obter um exsudato peritoneal contendo $95 \%$ de neutrófilos, foi utilizado o modelo de peritonite. Para tanto, os animais foram anestesiados com uma solução composta por xilazina (Anasedan $®)$ e quetamina (Dopalen®), em uma proporção de 1:1. Os animais anestesiados foram injetados pela via intraperitoneal, com solução de carragenina 4,5 mg/kg em $1 \mathrm{ml}$ de tampão fosfato salina (PBS) estéril (pH 7,4). Após 4 horas, os animais foram sacrificados em $\mathrm{CO}_{2}$. A pele da região abdominal foi removida, a cavidade peritoneal lavada com $10 \mathrm{~mL}$ de PBS estéril $(\mathrm{pH} 7,4)$ e o exsudato coletado com o auxílio de pipeta Pasteur de polietileno. A suspensão de células peritoneais foi diluída na proporção de 1:60 com líquido de Thoma e a contagem total de células foi realizada em hemocitômetro de Neubauer.

\section{Atividade Fagocítica de Neutrófilos Mediada por Receptores para Fragmentos do Sistema Complemento (C3b/C3bi)}

Os neutrófilos $\left(1 \times 10^{6} / \mathrm{mL}\right)$ foram incubados por 40 minutos, a $37^{\circ} \mathrm{C}$, em atmosfera contendo 5\% de $\mathrm{CO}_{2}$ com $1 \mathrm{ml}$ de meio RPMI 1640 contendo partículas de zimosan opsonizado com soro homólogo $\left(5 \times 10^{6}\right.$ partículas $\left./ \mathrm{mL}\right)$, mantendo-se a proporção de células e partículas de zimosan, 1:5, respectivamente. Após a incubação, os esfregaços foram obtidos utilizando-se uma centrífuga citológica na rotação de $30 \mathrm{~g}$ durante 200 segundos.

As lâminas obtidas foram coradas pelo método pancrônico de Rosenfeld (Rosenfeld, 1947) e um total de 100 neutrófilos foi contado com o auxílio de 
microscopia óptica de luz utilizando-se objetiva de imersão. Do total de células contadas, foi avaliado o número de neutrófilos que não fagocitou nenhuma partícula, que fagocitou apenas uma, duas ou três ou mais. Esses valores foram multiplicados por seus respectivos scores como descrito abaixo:

Score

\begin{tabular}{|l|c|}
\hline Número de neutrófilos com nenhuma partícula fagocitada & x 0 \\
Número de neutrófilos com 1 partícula fagocitada & x 1 \\
Número de neutrófilos com 2 partículas fagocitadas & x 2 \\
Número de neutrófilos com 3 ou mais partículas fagocitadas & x 3 \\
\hline
\end{tabular}

O valor da atividade fagocítica para os 100 neutrófilos contados foi calculado pela soma dos valores obtidos em cada score (Corazzini, 1993, modificado).

\subsection{Opsonização das Partículas de Zimosan com Soro Homólogo}

Uma solução contendo $56 \mathrm{mg} / \mathrm{mL}$ de zimosan foi diluída 20 vezes em PBS (pH 7,4). O material foi incubado com soro obtido de ratos normais (fonte de fragmentos C3b/C3bi do sistema complemento), na proporção de $1: 1$, a $37^{\circ} \mathrm{C}$, sob agitação. Após 30 minutos, o material foi centrifugado a 2400 g, por 5 minutos. Após a centrifugação, o material foi ressuspenso em meio RPMI 1640 para utilização no ensaio de fagocitose.

\section{Ensaios Imunocitoquímicos para Análise da Fosforilação de Resíduos de Tirosina e da Polimerização de Actina}

Os neutrófilos $\left(1 \times 10^{6} / \mathrm{mL}\right)$ foram incubados por 5 ou 15 minutos, a $37^{\circ} \mathrm{C}$, em atmosfera contendo 5\% de $\mathrm{CO}_{2}$ com $1 \mathrm{ml}$ de meio RPMI 1640 contendo partículas de zimosan opsonizado com soro homólogo $\left(5 \times 10^{6}\right.$ partículas $\left./ \mathrm{mL}\right)$, mantendo-se a 
proporção de células e partículas de zimosan, 1:5, respectivamente. Após a incubação, os esfregaços foram obtidos utilizando-se uma centrífuga citológica na rotação de $30 \mathrm{~g}$ durante 200 segundos.

A seguir, as lâminas foram utilizadas em ensaios de imunocitoquímica para marcação de F-actina e fosfotirosina, segundo metodologia descrita por Allen (2007, modificado). As lâminas foram lavadas três vezes em tampão fosfato (PB) $0,1 \mathrm{M}$ (pH 7,4) e fixadas, por 5 minutos, em paraformaldeído $4 \%$ na presença de $\mathrm{PB} 0,1 \mathrm{M}(\mathrm{pH}$ 7,4) contendo Triton-X 100 0,2\%, para promover o rompimento da membrana celular. Após a fixação, as lâminas foram lavadas três vezes em PB 0,1 M (pH 7,4) e pósfixadas em etanol $95 \%$ a $-20^{\circ} \mathrm{C}$, por 5 minutos. Posteriormente, as lâminas foram lavadas 3 vezes em $\mathrm{PB}$ 0,1 $\mathrm{M}(\mathrm{pH} 7,4)$ e foi realizado o bloqueio das ligações inespecíficas com soro anti-IgG $0,5 \%$ (Sigma $\left.{ }^{\circledR}\right)$ durante 30 minutos à temperatura ambiente. Em seguida, as células foram incubadas na presença do anticorpo primário anti-fosfotirosina (anti-PTry puro, diluído 1:100 em PB, Sigma®), em temperatura ambiente e em câmara umidificada, por um período de aproximadamente 16 horas (overnight). Após a incubação com o anticorpo primário, as lâminas foram lavadas três vezes em $\mathrm{PB}$ 0,1 M ( $\mathrm{pH} \mathrm{7,4)} \mathrm{por} \mathrm{um} \mathrm{período} \mathrm{de} 10$ minutos por lavagem. Após este procedimento, as lâminas foram incubadas na presença do anticorpo secundário (FITC, diluído 1:200 em PB, Sigma®), por um período de 90 minutos no escuro. As lâminas foram novamente lavadas três vezes em $\mathrm{PB} 0,1 \mathrm{M}(\mathrm{pH} 7,4)$ por um período de 10 minutos para cada lavagem. Em seguida, para evidenciar os filamentos de actina, as lâminas foram incubadas com Faloídina conjugada a Rodamina (diluída 1:100 em PB, Invitrogen®), por um período de 30 minutos. As lâminas foram lavadas três vezes com PB 0,1 M (pH 7,4) por um período de 5 minutos por lavagem. Em seguida, para a visualização dos núcleos, as lâminas foram incubadas com 4', 6'-diamidini-2-fenilindol 
(DAPI, diluído 1:200 em PB, Sigma®) por um período de 15 minutos, seguido de três lavagens com PB 0,1 M (pH 7,4) de 5 minutos cada. As lâminas foram então analisadas em microscopia confocal e posteriormente a quantificação da intensidade de fluorescência nas amostras foi realizada no programa ImageJ. Em cada uma das imagens analisadas foram selecionadas 5 células para quantificação da intensidade de fluorescência. Os resultados expressam a média da intensidade de fluorescência de 4 imagens (4 animais), ou seja, 20 células por grupo experimental.

\section{Atividade Microbicida de Neutrófilos (Capacidade Fungicida)}

Os neutrófilos $\left(1 \times 10^{6} / \mathrm{mL}\right)$ foram incubados, por 2 horas, a $37^{\circ} \mathrm{C}$, em atmosfera contendo $5 \%$ de $\mathrm{CO}_{2}$ com $1 \mathrm{ml}$ de meio RPMI 1640 contendo leveduras de Candida albicans opsonizadas com soro homólogo $\left(3 \times 10^{6}\right.$ partículas $\left./ \mathrm{mL}\right)$, mantendo a proporção de 1 célula: 3 leveduras. Após a incubação, os esfregaços foram obtidos utilizando-se uma centrífuga citológica na rotação de $30 \mathrm{~g}$ durante 200 segundos. As lâminas foram coradas pelo método pancrônico de Rosenfeld (Rosenfeld, 1947) e a atividade microbicida determinada pelo teste de coloração de exclusão, uma vez que o corante Rosenfeld penetra apenas em células vivas (Corazzini, 1993). Um total de 100 neutrófilos que fagocitaram foi contado e os resultados foram expressos em porcentagem estabelecendo-se uma relação entre o total de leveduras fagocitadas e o total de leveduras mortas.

\subsection{Obtenção e Opsonização de Candida albicans}

O fungo Candida albicans foi cultivado em meio Sabouraud dextrose 20\%, a $37^{\circ} \mathrm{C}$, por 24 horas, para a obtenção da forma de levedura do fungo. Após o cultivo, o fungo foi coletado com uma alça de platina e ressuspenso em PBS (pH 7,4). A 
suspensão contendo $3 \times 10^{6}$ leveduras foi incubada com soro de rato normal (fonte de fragmentos $\mathrm{C} 3 \mathrm{~b} / \mathrm{C} 3$ bi do sistema complemento), na proporção de $1: 1$, a $37^{\circ} \mathrm{C}$, sob agitação. Após 30 minutos, o material foi centrifugado a 2400 g por 5 minutos e ressuspenso em meio RPMI 1640 para utilização no ensaio de atividade microbicida.

\section{Produção de Espécies Reativas do Oxigênio por Neutrófilos}

\subsection{Atividade da Enzima NADPH Oxidase - Produção de Ânion Superóxido por Neutrófilos}

A atividade da enzima NADPH oxidase nos neutrófilos foi avaliada pela produção de ânion superóxido, cujo princípio baseia-se na redução do citocromo c pelo $\mathrm{O}_{2}^{-}$gerado pelos neutrófilos (Pick \& Mizel, 1981). Neutrófilos $\left(4 \times 10^{5} / \mathrm{mL}\right.$ ) foram centrifugados a $2400 \mathrm{~g}$ por 5 minutos e incubados com $1 \mathrm{~mL}$ da solução de citocromo c 0,8 $\mathrm{M}$ e $25 \mathrm{ng}$ de phorbol 12-myristate 13-acetate (PMA, Sigma $\left.{ }^{\circledR}\right)$ por 1 hora, a $37^{\circ} \mathrm{C}$, em atmosfera contendo $5 \%$ de $\mathrm{CO}_{2}$. O mesmo ensaio foi realizado na presença de superóxido dismutase (SOD, $10 \mu \mathrm{g}$ - 37,8 U, Sigma®) e na ausência de PMA, controles negativo e da produção basal, respectivamente. Após 1 hora, a reação foi interrompida pela imersão dos tubos em banho de gelo por 10 minutos. A seguir, os tubos foram centrifugados a 2400 g por 5 minutos e o sobrenadante foi separado e plaqueado para leitura por espectrofotometria em comprimento de onda de $550 \mathrm{~nm}$, contra um branco constituído por solução de citocromo c $0,8 \mathrm{M}$. Como um mol de $\mathrm{O}_{2}{ }^{-}$reduz um mol de citocromo c, pode-se quantificar o $\mathrm{O}_{2}^{-}$através da seguinte expressão (Campbell e Campbell, 1986):

$$
\begin{aligned}
& \text { C = A / E.D, onde: } \\
& \text { C: Concentração de citocromo c na amostra. }
\end{aligned}
$$


A: Absorbância da amostra.

E: Coeficiente de extinção molar. Para o citocromo c, E = 21 mM (Pick e Mizel, 1981).

D: Comprimento do curso da luz (espessura da cubeta $\mathrm{em} \mathrm{cm}$ ).

Os resultados foram apresentados em $\mu \mathrm{M}$ de $\mathrm{O}_{2}^{-} / 4 \times 10^{5}$ neutrófilos / hora e representam a média das duplicatas das amostras subtraindo-se a média dos tubos controles que contém SOD.

\subsection{Produção de Peróxido de Hidrogênio por Neutrófilos}

Para a determinação da produção de peróxido de hidrogênio foi utilizada a técnica descrita por Pick e Keisari (1980), adaptada para micro ensaio por Pick e Mizel (1981). A técnica baseia-se na reação de oxidação do fenol vermelho pelo $\mathrm{H}_{2} \mathrm{O}_{2}$, a qual é catalisada pela enzima peroxidase. Neutrófilos $(4 \times 10 \% \mathrm{~mL})$ foram centrifugados a $2400 \mathrm{~g}$, por 5 minutos e ressuspensos em $1 \mathrm{~mL}$ de solução de fenol vermelho. Alíquotas de $100 \mu 1$ dessa suspensão (4x10 células) e $10 \mu \mathrm{l}$ da solução de PMA (25 ng) foram adicionadas em poços de placa de cultura. A placa foi incubada por 1 hora, a $37^{\circ} \mathrm{C} \mathrm{e} \mathrm{em}$ atmosfera contendo $5 \%$ de $\mathrm{CO}_{2}$. Após esse período, a reação foi interrompida pela adição de $20 \mu \mathrm{l}$ da solução de hidróxido de sódio $1 \mathrm{~N}$. A placa foi centrifugada e a absorbância do sobrenadante determinada por espectrofotometria em comprimento de onda de $610 \mathrm{~nm}$, contra um branco constituído por solução de fenol vermelho. A quantificação foi realizada utilizando-se uma curva padrão de $\mathrm{H}_{2} \mathrm{O}_{2}(5-40 \mu \mathrm{M})$ e os resultados foram apresentados em $\mu \mathrm{M}$ de $\mathrm{H}_{2} \mathrm{O}_{2} / 4 \times 10^{5}$ neutrófilos / hora.

\subsection{Produção de Ácido Hipocloroso por Neutrófilos}

A produção de ácido hipocloroso por neutrófilos foi avaliada pela técnica 
descrita por Dypbukt e col. (2005). Nesta técnica, o $\mathrm{HOCl}$ gerado pela ação da mieloperoxidase sobre $\mathrm{o} \mathrm{H}_{2} \mathrm{O}_{2}$ formado nos neutrófilos reage com a taurina formando taurina cloroamina. Em meio ácido e na presença de iodeto, a taurina cloroamina é oxidada, havendo a formação de ácido hipoiodoso, o qual oxida o cromóforo tetrametilbenzidina (TMB), gerando assim um produto de coloração azulada. Neutrófilos $\left(2 \times 10^{6} / \mathrm{mL}\right)$ foram centrifugados a $2400 \mathrm{~g}$, por 5 minutos e ressuspensos em $1 \mathrm{~mL}$ de solução de taurina $5 \mathrm{mM}$. Alíquotas de $100 \mu \mathrm{l}$ dessa suspensão $\left(2 \times 10^{5}\right.$ cél) e 10 $\mu l$ da solução de PMA (25 ng) foram adicionados em poços de placa de cultura. A placa foi incubada por 1 hora, a $37^{\circ} \mathrm{C}$ e em atmosfera contendo $5 \%$ de $\mathrm{CO}_{2}$. Após esse período a reação foi interrompida pela adição de $20 \mu \mathrm{g} / \mathrm{mL}$ de catalase e os tubos foram mantidos por pelo menos 10 minutos em banho de gelo. A seguir, os tubos foram centrifugados a $2400 \mathrm{~g}$ por 5 minutos e o sobrenadante foi separado e plaqueado. Ao sobrenadante adicionou-se $50 \mu 1$ de solução de TMB $2 \mathrm{mM}$, iodeto de potássio $10 \mu \mathrm{M} \mathrm{e}$ $10 \%$ de dimetilformamida em tampão acetato $400 \mathrm{mM}$, pH 5,4. Após 5 minutos, a leitura correspondente à redução do TMB foi realizada por espectrofotometria em comprimento de onda de $650 \mathrm{~nm}$, contra um branco constituído por solução de taurina. A quantificação foi realizada utilizando-se uma curva padrão de $\mathrm{HOCl}(5-80 \mu \mathrm{M})$ e os resultados foram apresentados em $\mu \mathrm{M}$ de $\mathrm{HOCl} / 2 \times 10^{5}$ neutrófilos / hora.

\section{Tratamentos}

9.1. Efeito in vitro da Crotoxina (Pico II) e dos demais Picos (I e III) sobre a Atividade Fagocítica de Neutrófilos

Como apresentado no item 3, durante o processo de purificação da CTX, são obtidos três picos (I, II e III), sendo o pico II correspondente a CTX. Com o intuito de 
caracterizar o componente responsável pelo efeito inibitório do VCdt sobre a atividade fagocítica de neutrófilos, foram realizados tratamentos in vitro com os picos I, II ou III. Para tanto os neutrófilos foram incubados por 1 hora com a CTX (pico II), ou com o pico I ou III, nas concentrações de 0,$02 ; 0,04 ; 0,08 ; 0,16$ ou $0,32 \mu \mathrm{g} / \mathrm{mL}$, acrescentadas ao meio RPMI 1640. O grupo controle foi constituído de neutrófilos incubados apenas na presença do meio. As concentrações utilizadas foram baseadas em estudos anteriores (Sampaio et al., 2003).

\subsection{Efeito in vivo da Crotoxina sobre a Atividade Fagocítica de Neutrófilos}

Uma vez caracterizado que a CTX é o componente responsável pelo efeito inibitório do VCdt sobre a fagocitose por neutrófilos, foram realizados os ensaios in vivo, em que a CTX foi administrada pela via subcutânea na dose de $0,1 \mathrm{mg} / \mathrm{kg}$. A concentração da CTX foi determinada a partir de dados da literatura que indicam que a CTX corresponde a 59\% do veneno bruto (Slotta \& Fraenkel-Conrat, 1938) e estão de acordo com Sampaio e col. (2003). Grupos controles foram constituídos por animais tratados com o mesmo volume de salina, nas mesmas condições experimentais. Duas horas, 1, 4 ou 14 dias após ou 1 hora antes da injeção de CTX ou salina, os animais foram injetados com carragenina, pela via intraperitoneal.

\subsection{Efeito in vitro e in vivo do VCdt e da Crotoxina sobre a Fosforilação de Resíduos de Tirosina e a Polimerização de Actina}

Nos ensaios in vitro, os neutrófilos foram incubados por 1 hora com o VCdt $(0,5$ $\mu \mathrm{g} / \mathrm{mL})$ ou a CTX $(0,08 \mu \mathrm{g} / \mathrm{mL})$, acrescentados ao meio RPMI 1640. O grupo controle foi constituído de neutrófilos incubados apenas na presença do meio.

Para os ensaios in vivo, a CTX ou o VCdt foram administrados pela via 
subcutânea nas doses de $0,18 \mathrm{mg} / \mathrm{kg}$ e $0,1 \mathrm{mg} / \mathrm{kg}$, respectivamente, 2 horas antes da injeção intraperitoneal de carragenina. Grupos controles foram constituídos por animais tratados com o mesmo volume de salina, nas mesmas condições experimentais.

\subsection{Efeito in vitro e in vivo do VCdt e da Crotoxina sobre a Atividade Microbicida de Candida albicans por Neutrófilos}

Para a avaliação do efeito in vitro do VCdt e da CTX sobre a atividade microbicida de neutrófilos, as células foram incubadas com diferentes concentrações de VCdt $(0,125 ; 0,25 ; 0,5 ; 1,0$ ou $2,0 \mu \mathrm{g} / \mathrm{mL})$ ou CTX $(0,02 ; 0,04 ; 0,08 ; 0,16$ ou 0,32 $\mu \mathrm{g} / \mathrm{mL}$ ) acrescentadas ao meio RPMI 1640. O grupo controle foi constituído de neutrófilos incubados apenas na presença do meio.

Para os ensaios in vivo, os animais foram tratados com VCdt ou CTX nas doses de $0,18 \mu \mathrm{g} / \mathrm{mL}$ e $0,1 \mu \mathrm{g} / \mathrm{mL}$, respectivamente, 2 horas antes da administração intraperitoneal de carragenina. Grupos controles foram constituídos por animais tratados com o mesmo volume de salina, nas mesmas condições experimentais.

\subsection{Efeito in vitro e in vivo do VCdt e da CTX sobre a Produção de Espécies Reativas do Oxigênio por Neutrófilos}

Para os ensaios in vitro que avaliaram o efeito do VCdt e da CTX sobre a produção de ânion superóxido, peróxido de hidrogênio e ácido hipocloro, as células foram incubadas com diferentes concentrações de VCdt $(0,25 ; 0,5$ ou $1,0 \mu \mathrm{g} / \mathrm{mL})$ ou CTX $(0,02 ; 0,04$ ou $0,08 \mu \mathrm{g} / \mathrm{mL})$, acrescentadas ao meio RPMI 1640. O grupo controle foi constituído de neutrófilos incubados apenas na presença do meio.

Para os ensaios in vivo, os animais foram tratados com VCdt ou CTX nas doses de $0,18 \mu \mathrm{g} / \mathrm{mL}$ e $0,1 \mu \mathrm{g} / \mathrm{mL}$, respectivamente, 2 horas antes da administração 
intraperitoneal de carragenina. Grupos controles foram constituídos por animais tratados com o mesmo volume de salina, nas mesmas condições experimentais.

\section{Análise Estatística}

Os valores foram expressos como média \pm EPM (erro padrão da média) e analisados estatisticamente por ANOVA e teste de Tukey-Kramer (INSTAT GraphPad Software). 
Resultados 


\section{RESULTADOS}

1. Efeito in vitro da Crotoxina (Pico II) e dos demais Picos (I e III) sobre a Atividade Fagocítica de Neutrófilos Mediada por Receptores para Fragmentos do Sistema Complemento (C3b/C3bi)

Como mostra a Figura 1, a incubação dos neutrófilos com a CTX (pico II), por 1 hora, em diferentes concentrações, reduziu a fagocitose realizada por essas células, quando comparado ao grupo controle. Essa redução foi de 29\%, 24\%, 28\%, $26 \%$ e 24\%, respectivamente para as concentrações 0,$02 ; 0,04 ; 0,08 ; 0,16$ e $0,32 \mu \mathrm{g} / \mathrm{mL}$, não sendo observada diferença estatística significante entre essas concentrações. Essa inibição foi semelhante à observada para o VCdt bruto.

Ainda, a incubação de neutrófilos com os picos I ou III, por 1 hora, nas diversas concentrações $(0,02 ; 0,04 ; 0,08 ; 0,16$ e $0,32 \mu \mathrm{g} / \mathrm{mL})$, não alterou a atividade fagocítica dessas células (Figura 2). 


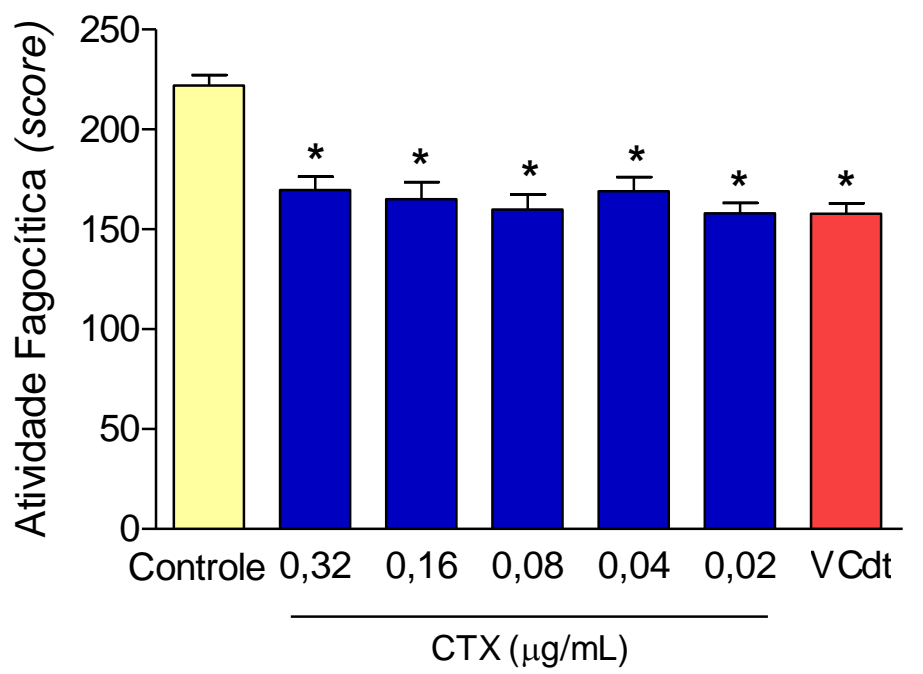

Figura 1. Efeito in vitro da CTX (pico II) sobre a fagocitose por neutrófilos. Os neutrófilos foram obtidos do exsudato peritoneal, 4 horas após a administração intraperitoneal de carragenina $(4,5 \mathrm{mg} / \mathrm{kg})$. As células $\left(1 \times 10^{6}\right)$ foram incubadas por 1 hora com diferentes concentrações de $\operatorname{CTX}(0,02 ; 0,04 ; 0,08 ; 0,16$ ou $0,32 \mu \mathrm{g} / \mathrm{mL})$ ou com VCdt total $(0,5 \mu \mathrm{g} / \mathrm{mL})$. Neutrófilos incubados somente na presença de meio RPMI 1640 foram utilizados como controle. Partículas de zimosan opsonizado com soro de ratos normais $\left(5 \times 10^{6}\right)$ foram utilizadas como estímulo fagocítico. Um total de 100 células foi contado e a atividade fagocítica determinada. Os resultados correspondem à média \pm SEM de 5 animais. * $\mathrm{P}<0,001$; significativamente diferente do grupo controle. 
A

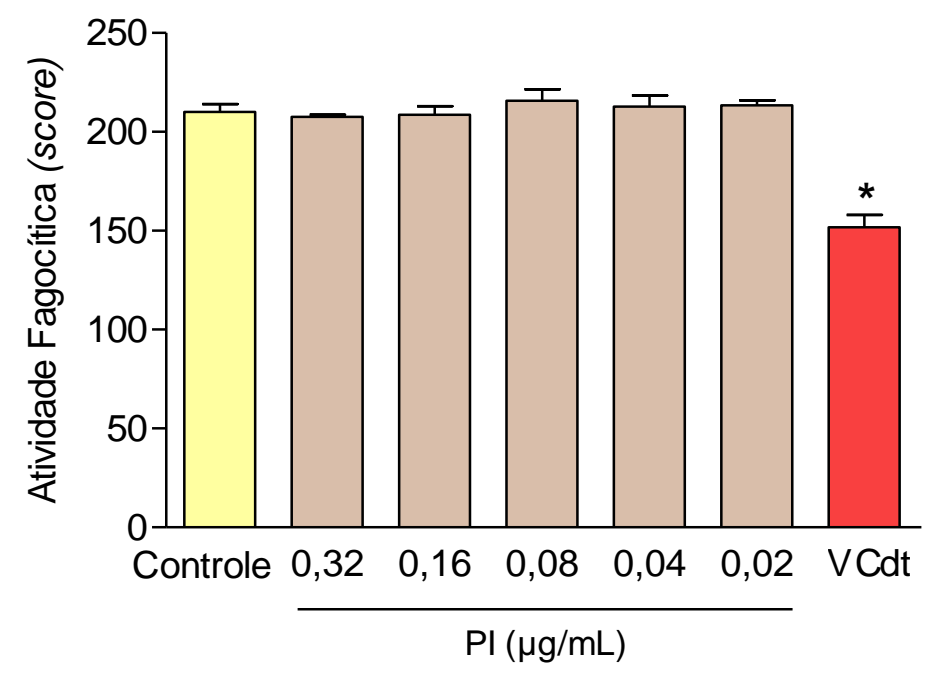

B

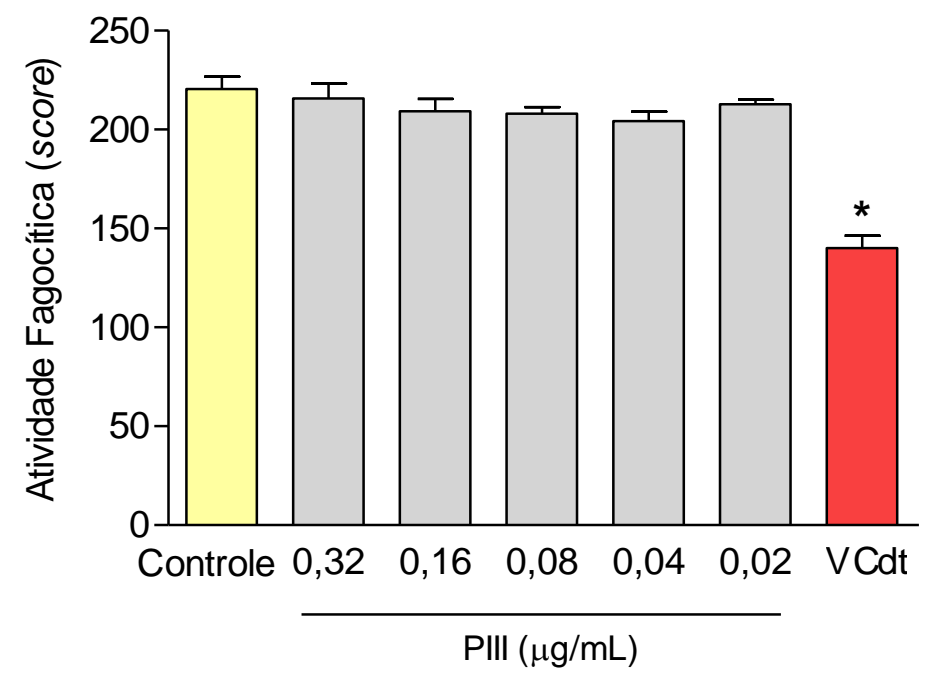

Figura 2. Efeito in vitro dos picos I (A) e III (B) sobre a fagocitose por neutrófilos. Os neutrófilos foram obtidos do exsudato peritoneal, 4 horas após a administração intraperitoneal de carragenina $(4,5 \mathrm{mg} / \mathrm{kg})$. As células $\left(1 \times 10^{6}\right)$ foram incubadas por 1 hora com diferentes concentrações dos picos I ou III $(0,02 ; 0,04 ; 0,08 ; 0,16$ ou 0,32 $\mu \mathrm{g} / \mathrm{mL})$ ou com VCdt total $(0,5 \mu \mathrm{g} / \mathrm{mL})$. Neutrófilos incubados somente na presença de meio RPMI 1640 foram utilizados como controle. Partículas de zimosan opsonizado com soro de ratos normais $\left(5 \times 10^{6}\right)$ foram utilizadas como estímulo fagocítico. Um total de 100 células foi contado e a atividade fagocítica determinada. Os resultados correspondem à média \pm SEM de 5 animais. $* \mathrm{P}<0,001$; significativamente diferente do grupo controle. 
2. Efeito in vivo da Crotoxina sobre a Atividade Fagocítica de Neutrófilos Mediada por Receptores para Fragmentos do Sistema Complemento (C3b/C3bi)

Os resultados apresentados na Figura 3 mostram que o tratamento dos animais com a CTX $(0,1 \mathrm{mg} / \mathrm{kg})$ reduziu a atividade fagocítica dos neutrófilos, em todos os tempos avaliados, quando comparado aos animais tratados apenas com salina (controle). Essa redução foi de $24 \%, 31 \%, 25 \%$, $18 \%$ e $35 \%$, respectivamente para os tempos de tratamento de 2 horas, 1, 4 e 14 dias antes e 1 hora após a administração intraperitoneal de carragenina. Não foi observada diferença estatística nas porcentagens de inibição nos diferentes tempos de tratamento com a CTX. 


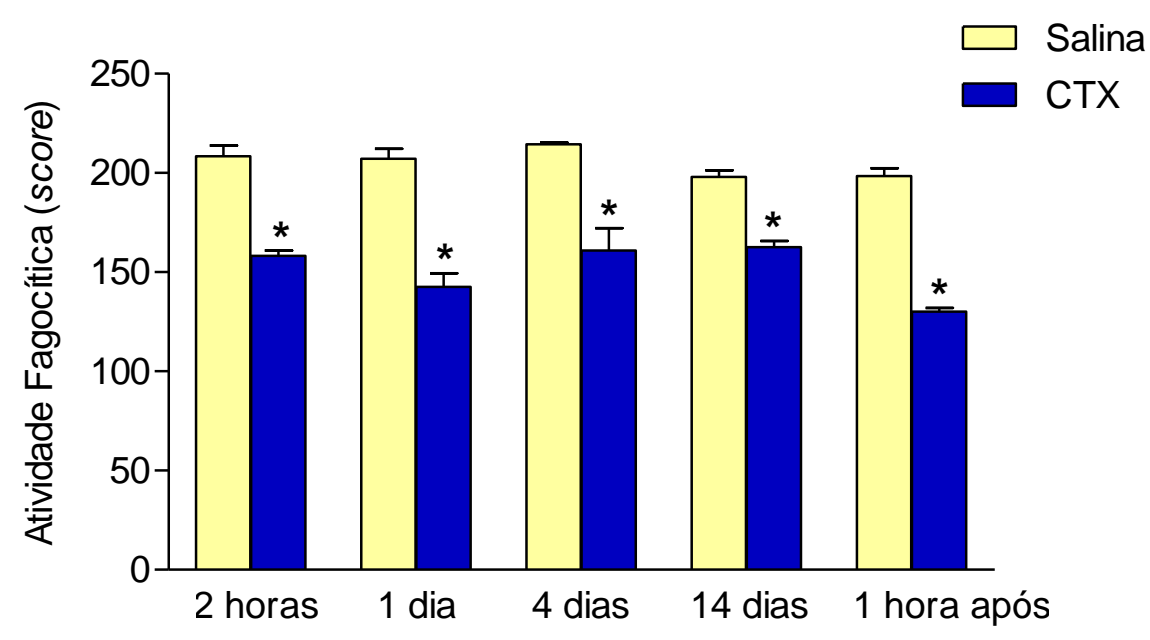

Figura 3. Efeito in vivo da CTX sobre a fagocitose por neutrófilos. CTX $(0,1 \mathrm{mg} / \mathrm{kg})$ ou salina estéril (controle) foi injetada pela via subcutânea em ratos 2 horas, 1, 4 ou 14 dias antes ou 1 hora após a administração intraperitoneal de carragenina (4,5 mg/kg). Partículas de zimosan opsonizado com soro de ratos normais $\left(5 \times 10^{6}\right)$ foram utilizadas como estímulo fagocítico. Um total de 100 células foi contado e a atividade fagocítica determinada. Os resultados correspondem à média \pm SEM de 5 animais. * $\mathrm{P}<0,001$; significativamente diferente do grupo controle. 


\section{Efeito in vitro e in vivo do VCdt e da Crotoxina sobre a Fosforilação de Resíduos de Tirosina e a Polimerização de Actina}

Com a finalidade de caracterizar o efeito inibitório do VCdt e da CTX sobre a fagocitose por neutrófilos foram investigados seus efeitos sobre a fosforilação de resíduos de tirosina e a polimerização de actina em fagossomas nascentes (fagocitose por 5 minutos) e fagossomas maduros (fagocitose por 15 minutos).

Neutrófilos incubados com o VCdt $(0,5 \mu \mathrm{g} / \mathrm{mL})$ ou com a CTX $(0,08 \mu \mathrm{g} / \mathrm{mL})$ e submetidos ao ensaio de fagocitose de partículas de zimosan opsonizado por 5 minutos apresentaram significativa redução na marcação de fosfotirosina e F-actina, quando comparado ao grupo controle, neutrófilos incubados apenas na presença meio RPMI 1640. Para a marcação de fosfotirosina, a inibição foi de $89 \%$ e $98 \%$ para as células incubadas com VCdt (Figuras 4e e 5) ou CTX (Figuras 4f e 5), respectivamente. Em relação à marcação de F-actina, a inibição foi de $71 \%$ e $80 \%$ quando os neutrófilos foram incubados com VCdt (Figuras 4h e 5) ou CTX (Figuras 4i e 5), respectivamente. Neutrófilos incubados apenas na presença de meio RPMI 1640 (controle) apresentaram intensa marcação de fosfotirosina (Figura 4d) e F-actina (Figura 4g) nas regiões da membrana plasmática envolvidas na formação de fagossomas.

Após 15 minutos de fagocitose, neutrófilos incubados com o VCdt $(0,5 \mu \mathrm{g} / \mathrm{mL})$ ou a CTX $(0,08 \mu \mathrm{g} / \mathrm{mL})$ apresentaram significativa redução na marcação de F-actina quando comparado ao grupo controle. Essa inibição foi de $70 \%$ quando as células foram incubadas com VCdt (Figuras 6h e 7) e 86\% quando incubadas com CTX (Figuras 6i e 7). Neutrófilos incubados apenas na presença de meio RPMI 1640 (controle) 
apresentaram fraca marcação de fosfotirosina (Figura 6d) e intensa marcação de Factina ao redor dos fagossomas formados (Figura 6g).

Nos ensaios in vivo, o pré-tratamento dos animais com o VCdt $(0,18 \mathrm{mg} / \mathrm{kg})$ ou a CTX $(0,1 \mathrm{mg} / \mathrm{kg}), 2$ horas antes da administração intraperitoneal de carragenina $(4,5$ $\mathrm{mg} / \mathrm{kg}$ ), inibiu a fosforilação de tirosina e a polimerização de actina em fagossomas nascentes (5 minutos de fagocitose), quando comparado ao grupo controle injetado com salina estéril. Para a marcação de fosfotirosina, essa inibição foi de $86 \%$ e $85 \%$ para os animais tratados com VCdt (Figuras 8b e 9) ou CTX (Figura 8c e 9), respectivamente. Em relação à marcação de F-actina, a inibição foi de $83 \%$ e $90 \%$ para os animais tratados com VCdt (Figuras 8e e 9) ou CTX (Figuras 8f e 9), respectivamente. Neutrófilos incubados apenas na presença de meio RPMI 1640 (controle) apresentaram intensa marcação de fosfotirosina (Figura 8a) e F-actina (Figura 8d) nas regiões da membrana plasmática envolvidas na formação de fagossomas. 

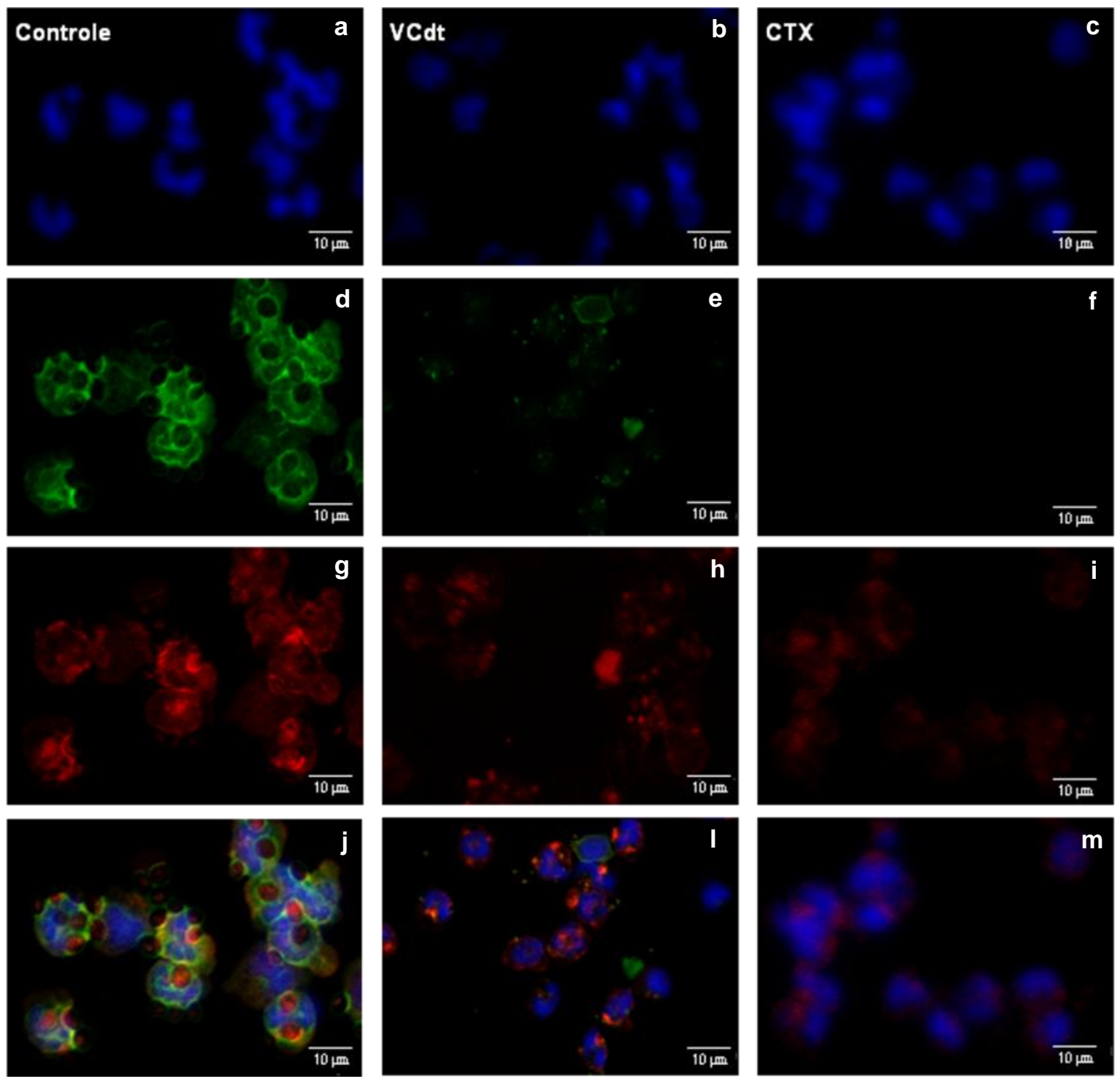

Figura 4. Efeito in vitro do VCdt e da CTX sobre a fosforilação de resíduos de tirosina e a polimerizaçăo de actina após 5 minutos de fagocitose. Os neutrófilos foram obtidos do exsudato peritoneal, 4 horas após a administração intraperitoneal de carragenina $(4,5 \mathrm{mg} / \mathrm{kg})$. As células $\left(1 \times 10^{6}\right)$ foram incubadas por 1 hora com VCdt $(0,5$ $\mu \mathrm{g} / \mathrm{mL})$ ou CTX $(0,08 \mu \mathrm{g} / \mathrm{mL})$. Neutrófilos incubados somente na presença de meio RPMI 1640 foram utilizados como controle. Após o período de incubação, os neutrófilos foram submetidos, por 5 minutos, ao ensaio de fagocitose de partículas de zimosan opsonizado $\left(5 \times 10^{6}\right)$ e a seguir foi realizada a marcação de fosfotirosina (antiPTry 1:100 + FITC 1:200) e F-actina (faloidina + rhodamina 1:100) por ensaios imunocitoquímicos. a, b e c representam as marcações do núcleo (DAPI); d, e e f representam as marcações de fosfotirosina (FITC); $\mathbf{g}, \mathbf{h}$ e $\mathbf{i}$ representam as marcações de F-actina (rhodamina) e $\mathbf{j}, \mathbf{l}$ e $\mathbf{m}$ representam as sobreposições das imagens. 


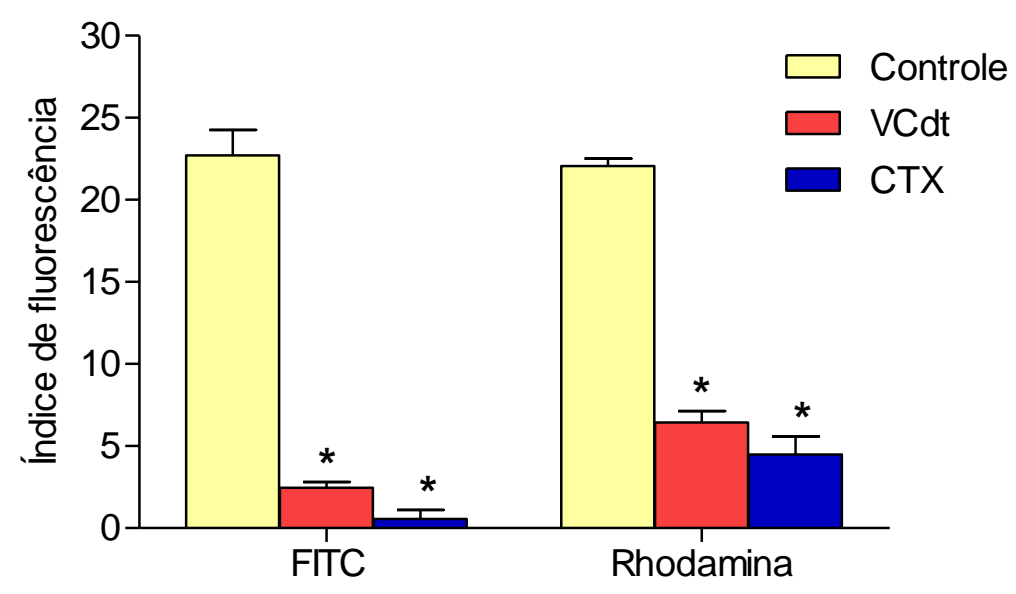

Figura 5. Efeito in vitro do VCdt e da CTX sobre a fosforilação de resíduos de tirosina e a polimerização de actina após 5 minutos de fagocitose. Os neutrófilos foram obtidos do exsudato peritoneal, 4 horas após a administração intraperitoneal de carragenina $(4,5 \mathrm{mg} / \mathrm{kg})$. As células $\left(1 \times 10^{6}\right)$ foram incubadas por 1 hora com VCdt $(0,5$ $\mu \mathrm{g} / \mathrm{mL})$ ou CTX $(0,08 \mu \mathrm{g} / \mathrm{mL})$. Neutrófilos incubados somente na presença de meio RPMI 1640 foram utilizados como controle. Após o período de incubação, os neutrófilos foram submetidos, por 5 minutos, ao ensaio de fagocitose de partículas de zimosan opsonizado $\left(5 \times 10^{6}\right)$ e a seguir foi realizada a marcação de fosfotirosina (antiPTry 1:100 + FITC 1:200) e F-actina (faloidina + rhodamina 1:100) por ensaios imunocitoquímicos. A quantificação das intensidades de fluorescência foi realizada no programa ImageJ. Os resultados correspondem à média \pm SEM de 4 animais. ${ }^{*} \mathrm{P}<0,001$; significativamente diferente do grupo controle. 

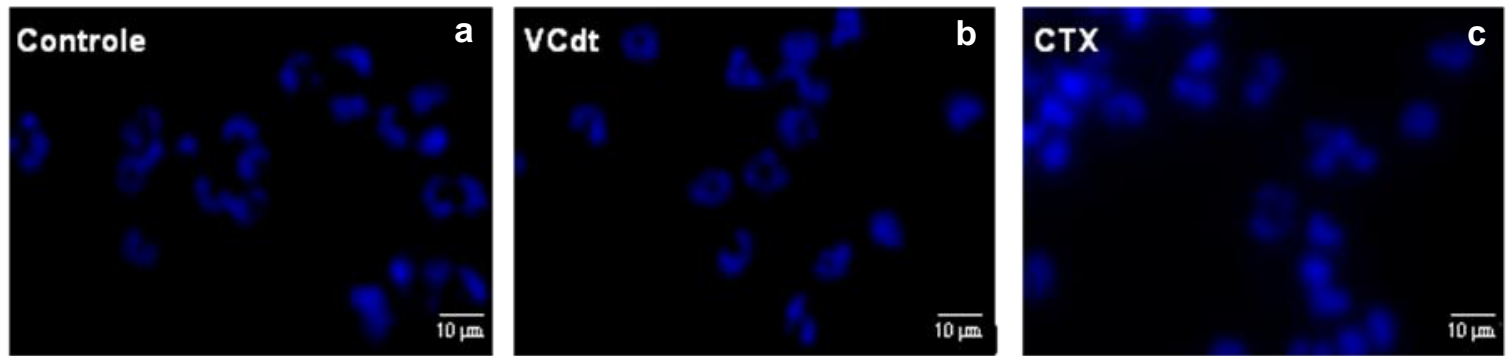

d
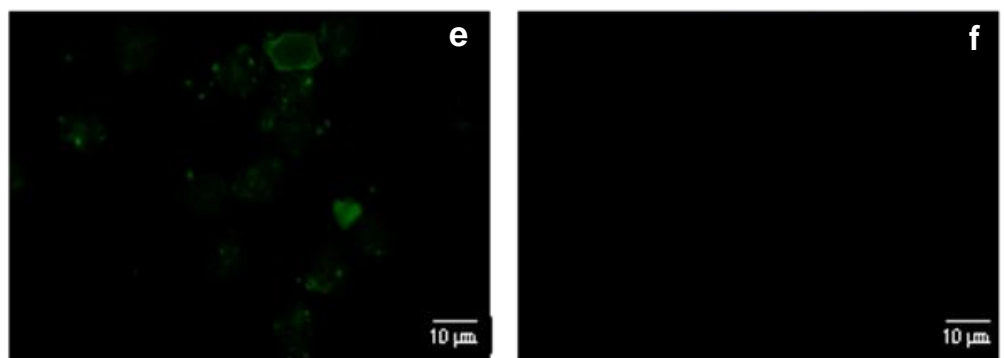

g
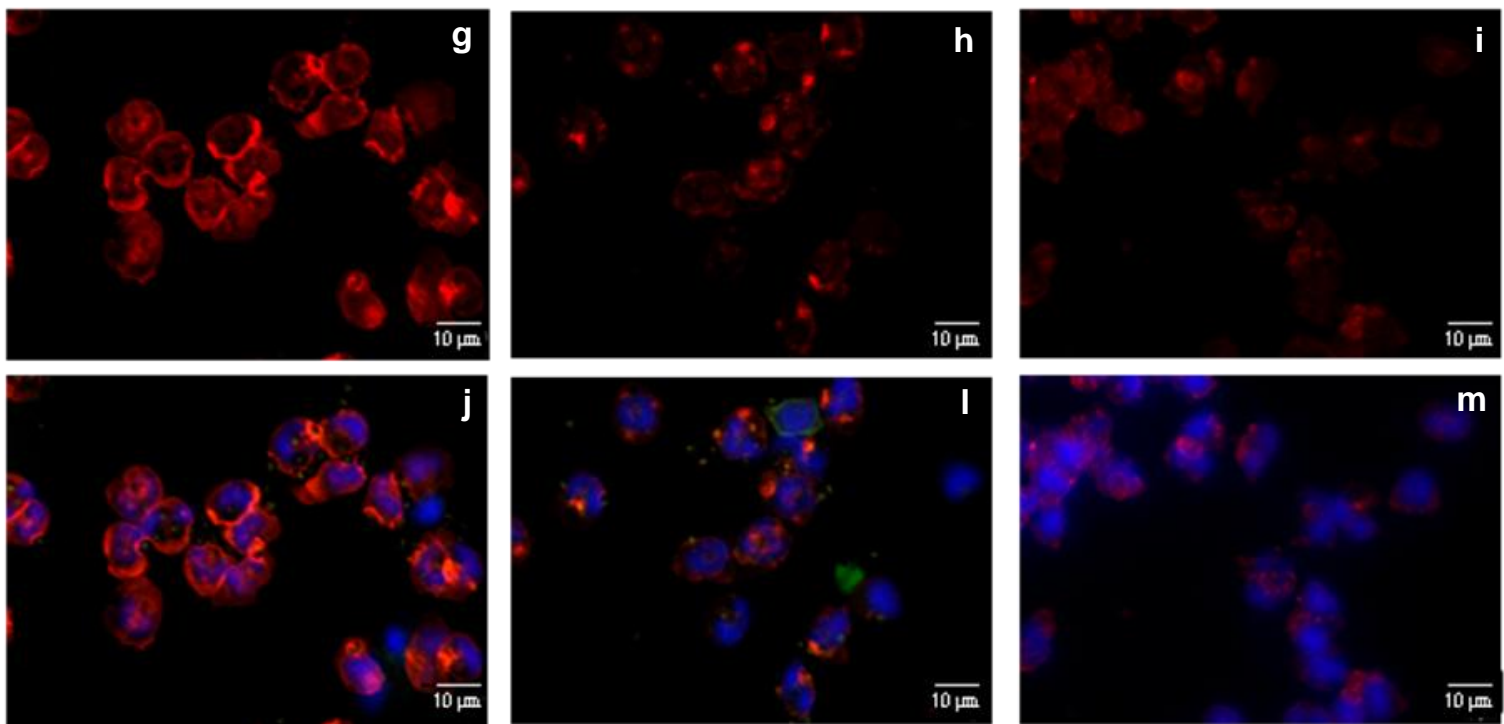

m

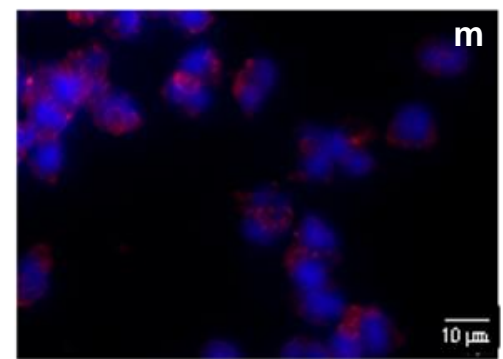

Figura 6. Efeito in vitro do VCdt e da CTX sobre a fosforilação de resíduos de tirosina e a polimerização de actina após 15 minutos de fagocitose. Os neutrófilos foram obtidos do exsudato peritoneal, 4 horas após a administração intraperitoneal de carragenina $(4,5 \mathrm{mg} / \mathrm{kg})$. As células $\left(1 \times 10^{6}\right)$ foram incubadas por 1 hora com VCdt $(0,5$ $\mu \mathrm{g} / \mathrm{mL})$ ou CTX $(0,08 \mu \mathrm{g} / \mathrm{mL})$. Neutrófilos incubados somente na presença de meio RPMI 1640 foram utilizados como controle. Após o período de incubação, os neutrófilos foram submetidos, por 15 minutos, ao ensaio de fagocitose de partículas de zimosan opsonizado $\left(5 \times 10^{6}\right)$ e a seguir foi realizada a marcação de fosfotirosina (antiPTry 1:100 + FITC 1:200) e F-actina (faloidina + rhodamina 1:100 ) por ensaios imunocitoquímicos. a, b e c representam as marcações do núcleo (DAPI); d, e e f representam as marcações de fosfotirosina (FITC); $\mathbf{g}, \mathbf{h}$ e $\mathbf{i}$ representam as marcações de F-actina (rhodamina) e $\mathbf{j}, \mathbf{l}$ e $\mathbf{m}$ representam as sobreposições das imagens. 


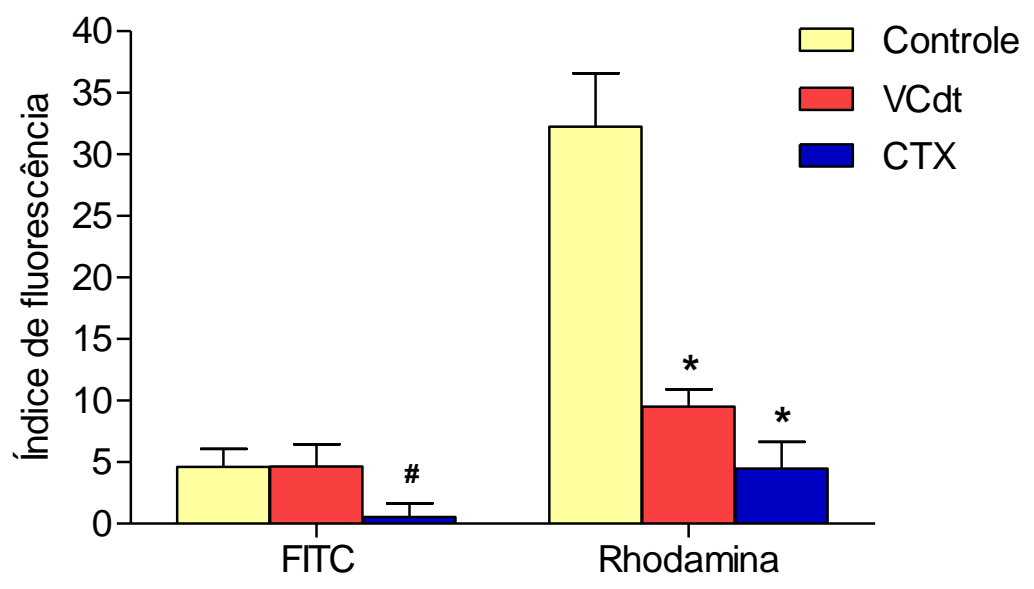

Figura 7. Efeito in vitro do VCdt e da CTX sobre a fosforilação de resíduos de tirosina e a polimerização de actina após 15 minutos de fagocitose. Os neutrófilos foram obtidos do exsudato peritoneal, 4 horas após a administração intraperitoneal de carragenina $(4,5 \mathrm{mg} / \mathrm{kg})$. As células $\left(1 \times 10^{6}\right)$ foram incubadas por 1 hora com VCdt $(0,5$ $\mu \mathrm{g} / \mathrm{mL})$ ou CTX $(0,08 \mu \mathrm{g} / \mathrm{mL})$. Neutrófilos incubados somente na presença de meio RPMI 1640 foram utilizados como controle. Após o período de incubação, os neutrófilos foram submetidos, por 15 minutos, ao ensaio de fagocitose de partículas de zimosan opsonizado $\left(5 \times 10^{6}\right)$ e a seguir foi realizada a marcação de fosfotirosina (antiPTry 1:100 + FITC 1:200) e F-actina (faloidina + rhodamina 1:100) por ensaios imunocitoquímicos. A quantificação das intensidades de fluorescência foi realizada no programa ImageJ. Os resultados correspondem à média \pm SEM de 4 animais. ${ }^{*} \mathrm{P}<0,001$; \# $\mathrm{P}<0,01$; significativamente diferente do grupo controle. 

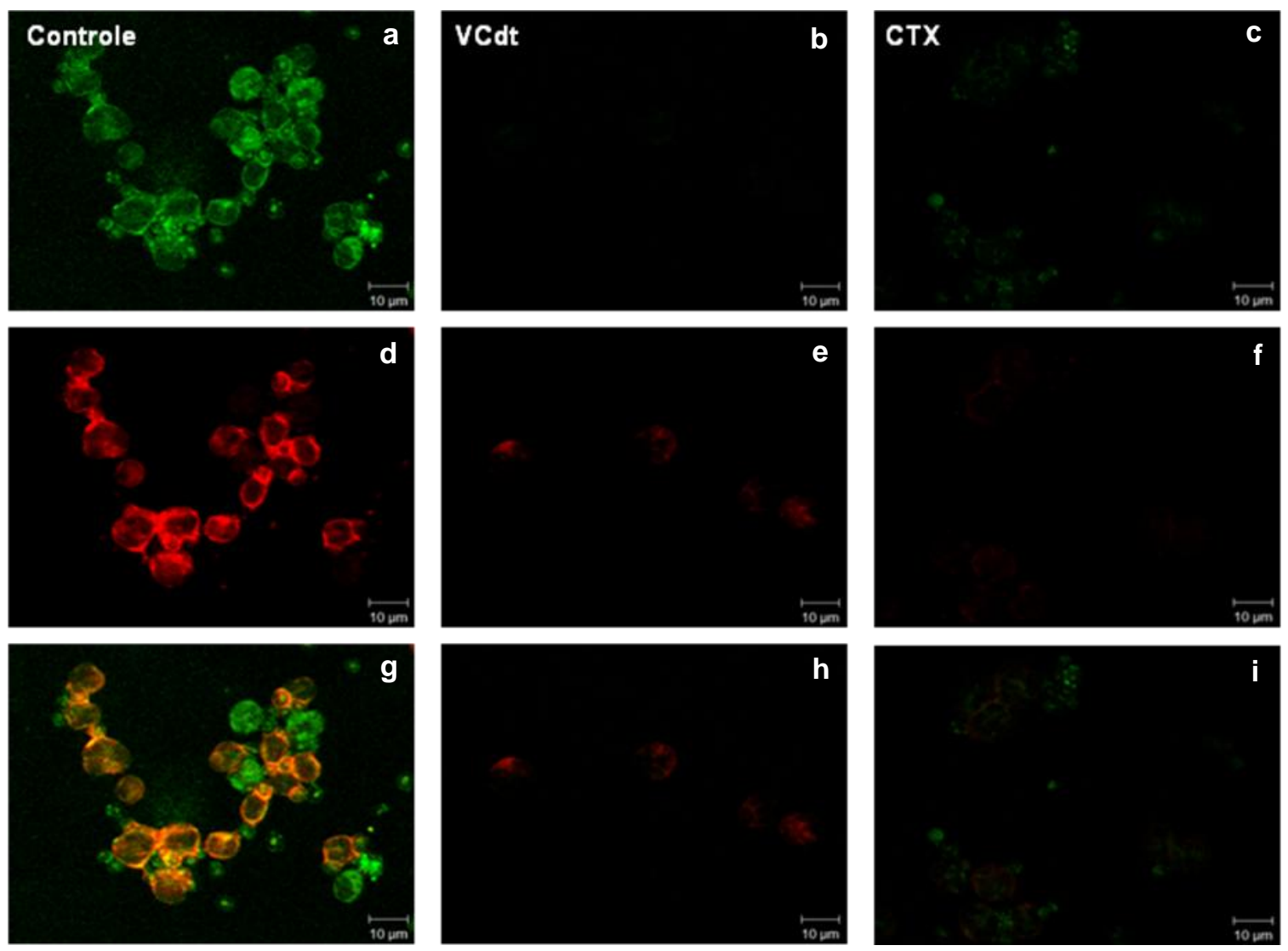

Figura 8. Efeito in vivo do VCdt e da CTX sobre a fosforilação de resíduos de tirosina e a polimerização de actina após 5 minutos de fagocitose. $\operatorname{VCdt}(0,18$ $\mathrm{mg} / \mathrm{kg})$, CTX $(0,1 \mathrm{mg} / \mathrm{kg})$ ou salina estéril (controle) foi injetado pela via subcutânea em ratos 2 horas antes da administração intraperitoneal de carragenina $(4,5 \mathrm{mg} / \mathrm{kg})$. Neutrófilos $\left(1 \times 10^{6}\right)$ coletados do exsudato peritoneal foram submetidos, por 15 minutos, ao ensaio de fagocitose de partículas de zimosan opsonizado $\left(5 \times 10^{6}\right)$ e a seguir foi realizada a marcação de fosfotirosina (anti-PTry 1:100 + FITC 1:200) e F-actina (faloidina + rhodamina 1:100) por ensaios imunocitoquímicos. a, b e c representam as marcações de fosfotirosina (FITC); d, e e f representam as marcações de F-actina (rhodamina) e $\mathbf{g}, \mathbf{h}$ e $\mathbf{i}$ representam as sobreposições das imagens. 


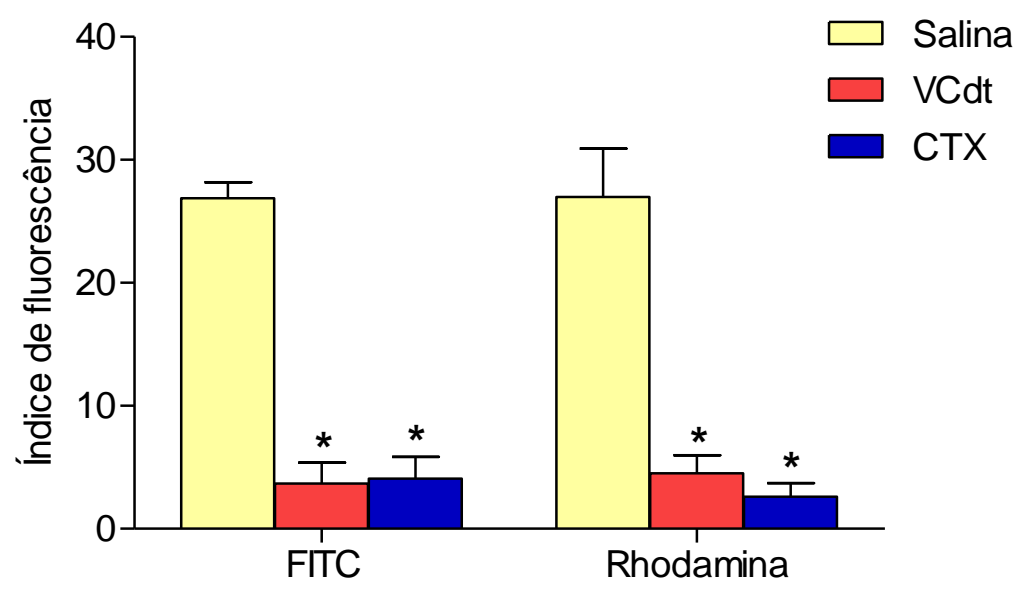

Figura 9. Efeito in vivo do VCdt e da CTX sobre a fosforilação de resíduos de tirosina e a polimerização de actina após 5 minutos de fagocitose. VCdt $(0,18$ $\mathrm{mg} / \mathrm{kg})$, CTX $(0,1 \mathrm{mg} / \mathrm{kg})$ ou salina estéril foi injetado pela via subcutânea em ratos, 2 horas antes da administração intraperitoneal de carragenina $(4,5 \mathrm{mg} / \mathrm{kg})$. Neutrófilos $\left(1 \times 10^{6}\right)$ coletados do exsudato peritoneal foram submetidos, por 5 minutos, ao ensaio de fagocitose de partículas de zimosan opsonizado $\left(5 \times 10^{6}\right)$ e a seguir foi realizada a marcação de fosfotirosina (anti-PTry 1:100 + FITC 1:200) e F-actina (faloidina + rhodamina 1:100) por ensaios imunocitoquímicos. A quantificação das intensidades de fluorescência foi realizada no programa ImageJ. Os resultados correspondem à média \pm SEM de 4 animais. * $\mathrm{P}<0,001$; significativamente diferente do grupo controle. 
4. Efeito in vitro e in vivo do VCdt e da Crotoxina sobre a Atividade Microbicida de Candida albicans por Neutrófilos

A incubação de neutrófilos com o VCdt $(0,125 ; 0,25 ; 0,5 ; 1,0$ ou 2,0 $\mu \mathrm{g} / \mathrm{mL})$ ou a $\operatorname{CTX}(0,02 ; 0,04 ; 0,08 ; 0,16$ ou $0,32 \mu \mathrm{g} / \mathrm{mL})$ não alterou significativamente a atividade microbicida de Candida albicans pelos neutrófilos, em nenhuma das concentrações avaliadas, quando comparado aos grupos controles incubados somente na presença de meio RPMI 1640 (Figura 12).

Além disso, o tratamento dos animais com o VCdt $(0,18 \mathrm{mg} / \mathrm{kg})$ ou a CTX $(0,1$ $\mathrm{mg} / \mathrm{kg}), 2$ horas antes da administração intraperitoneal de carragenina (4,5 mg/kg), não alterou a atividade microbicida dos neutrófilos quando comparado aos animais tratados apenas com salina (controle) (Figura 13). 
A

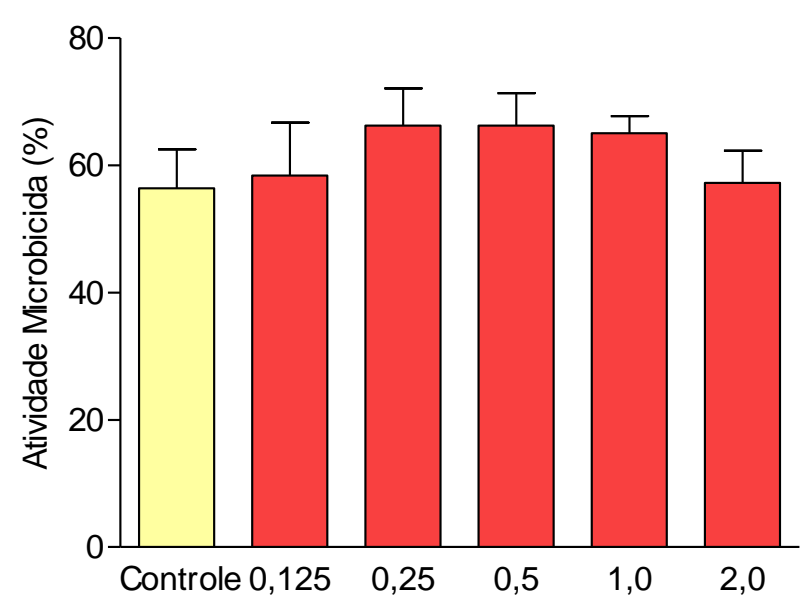

B

$\operatorname{VCdt}(\mu \mathrm{g} / \mathrm{mL})$

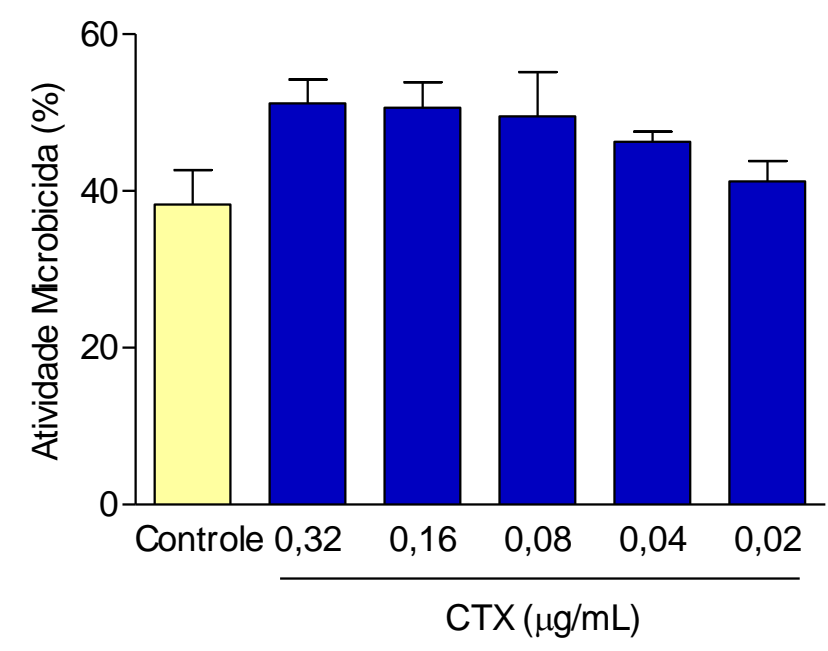

Figura 12. Efeito in vitro do VCdt (A) e da CTX (B) sobre a atividade microbicida de neutrófilos. Os neutrófilos foram obtidos do exsudato peritoneal, 4 horas após a administração intraperitoneal de carragenina $(4,5 \mathrm{mg} / \mathrm{kg})$. As células $\left(1 \times 10^{6}\right)$ foram incubadas por 1 hora com VCdt $(0,125 ; 0,25 ; 0,5 ; 1,0$ ou $2,0 \mu \mathrm{g} / \mathrm{mL})$ ou CTX $(0,02$; $0,04 ; 0,08 ; 0,16$ ou $0,32 \mu \mathrm{g} / \mathrm{mL})$. Neutrófilos incubados somente na presença de meio RPMI 1640 foram utilizados como controle. Leveduras de Candida albicans opsonizadas com soro de ratos normais $\left(3 \times 10^{6}\right)$ foram utilizadas como estímulo fagocítico. Um total de 100 neutrófilos que fagocitaram foi contado e a atividade microbicida determinada. Os resultados correspondem à média \pm SEM de 5 animais. 


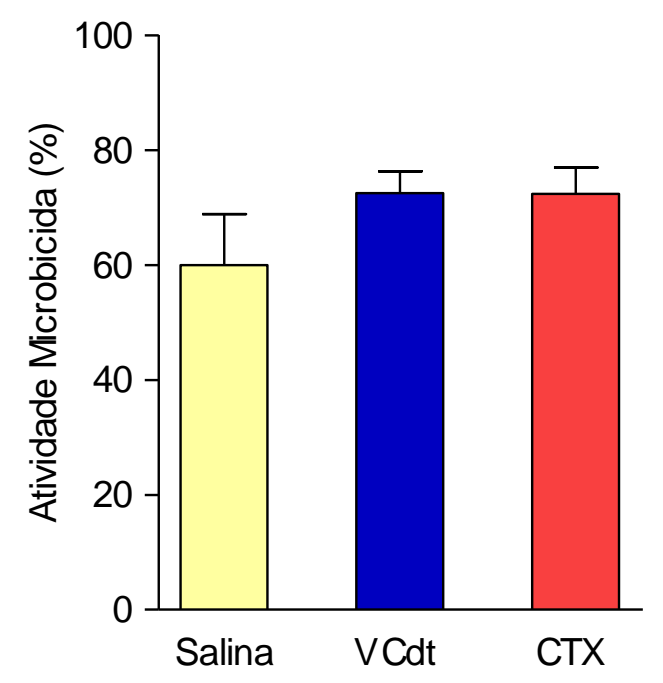

Figura 13. Efeito in vivo do VCdt e da CTX sobre a atividade microbicida de neutrófilos. Ratos foram administrados pela via subcutânea com VCdt $(0,18 \mathrm{mg} / \mathrm{kg})$, CTX $(0,1 \mathrm{mg} / \mathrm{kg})$ ou salina estéril (controle), 2 horas antes da administração intraperitoneal de carragenina $(4,5 \mathrm{mg} / \mathrm{kg})$. Leveduras de Candida albicans opsonizadas com soro de ratos normais $\left(3 \times 10^{6}\right)$ foram utilizadas como estímulo fagocítico. Um total de 100 neutrófilos foi contado e a atividade fagocítica determinada. Os resultados correspondem à média \pm SEM de 5 animais. 
5. Efeito in vitro e in vivo do VCdt e da Crotoxina sobre a Atividade da Enzima NADPH Oxidase em Neutrófilos

A atividade da enzima NADPH oxidase foi avaliada pela análise da produção de ânion superóxido pelos neutrófilos. Os resultados apresentados na Figura 14 mostram que a incubação de neutrófilos com o VCdt $(0,25 ; 0,5 ; 1,0 \mu \mathrm{g} / \mathrm{mL})$ ou a CTX $(0,02$; 0,04; $0,08 \mu \mathrm{g} / \mathrm{mL}$ ) não alterou a produção de ânion superóxido por essas células, em nenhuma das concentrações avaliadas, na presença ou na ausência de PMA, quando comparado aos respectivos grupos controles incubados somente na presença de meio RPMI 1640.

Ainda, o tratamento dos animais com o VCdt $(0,18 \mathrm{mg} / \mathrm{kg})$ ou a CTX $(0,1$ $\mathrm{mg} / \mathrm{kg}), 2$ horas antes da administração intraperitoneal de carragenina $(4,5 \mathrm{mg} / \mathrm{kg})$, não alterou a produção de ânion superóxido por essas células, na presença ou na ausência de PMA, quando comparado aos animais tratados com salina estéril (controle). (Figura 15). 
A
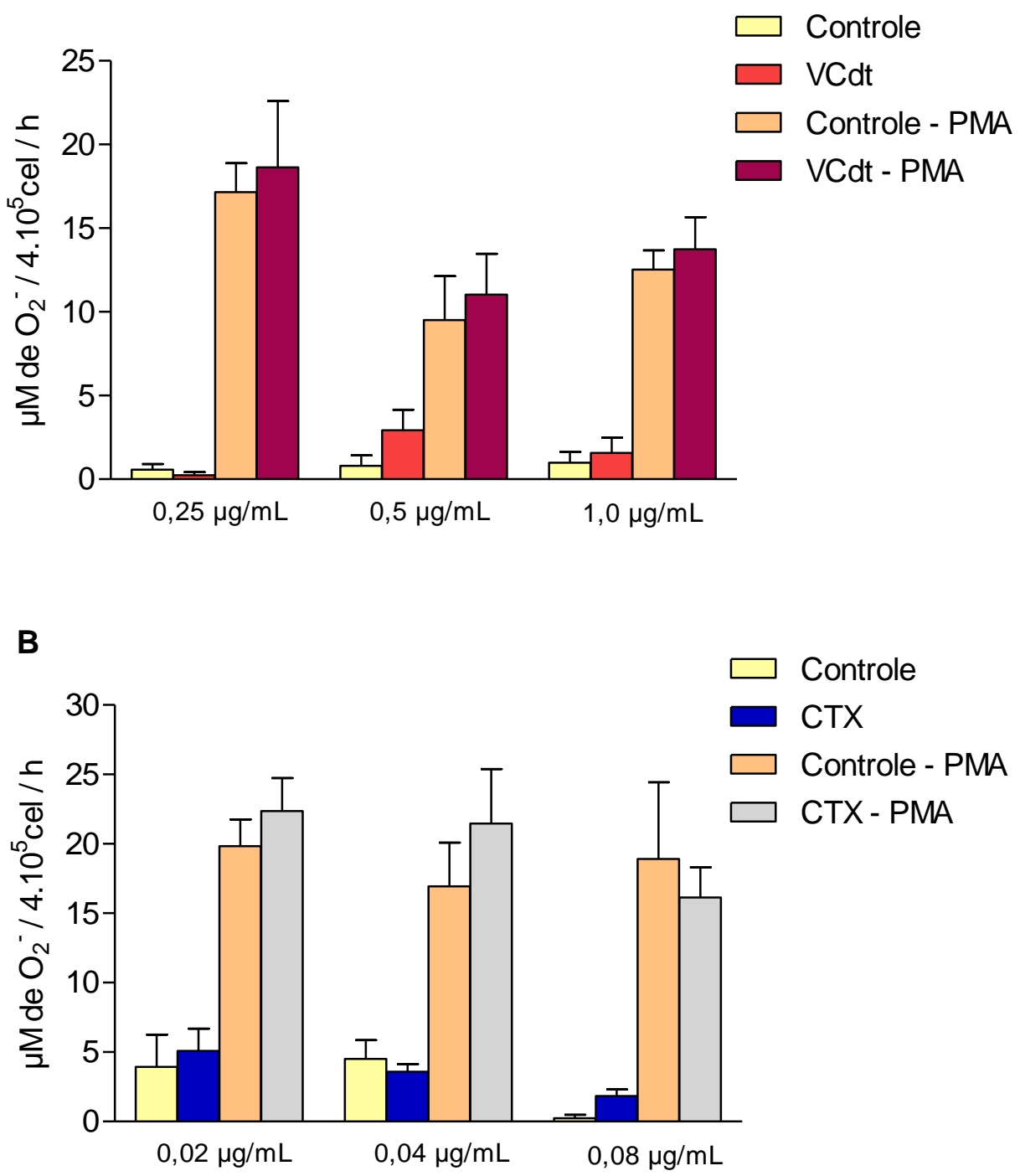

Figura 14. Efeito in vitro do VCdt (A) e da CTX (B) sobre a produção de ânion superóxido por neutrófilos. Neutrófilos $\left(4 \times 10^{5}\right)$ foram coletados 4 horas após a administração intraperitoneal de carragenina $(4,5 \mathrm{mg} / \mathrm{kg})$ e incubados por 1 hora com diferentes concentrações de VCdt $(0,25 ; 0,5$ ou $1,0 \mu \mathrm{g} / \mathrm{mL})$ ou CTX $(0,02 ; 0,04$ ou 0,08 $\mu \mathrm{g} / \mathrm{mL})$. Neutrófilos incubados somente na presença de meio RPMI 1640 foram utilizados como controle. Após o período de incubação, a produção de ânion superóxido foi avaliada na presença ou na ausência de PMA. Os resultados correspondem à média \pm SEM de 5 animais. 


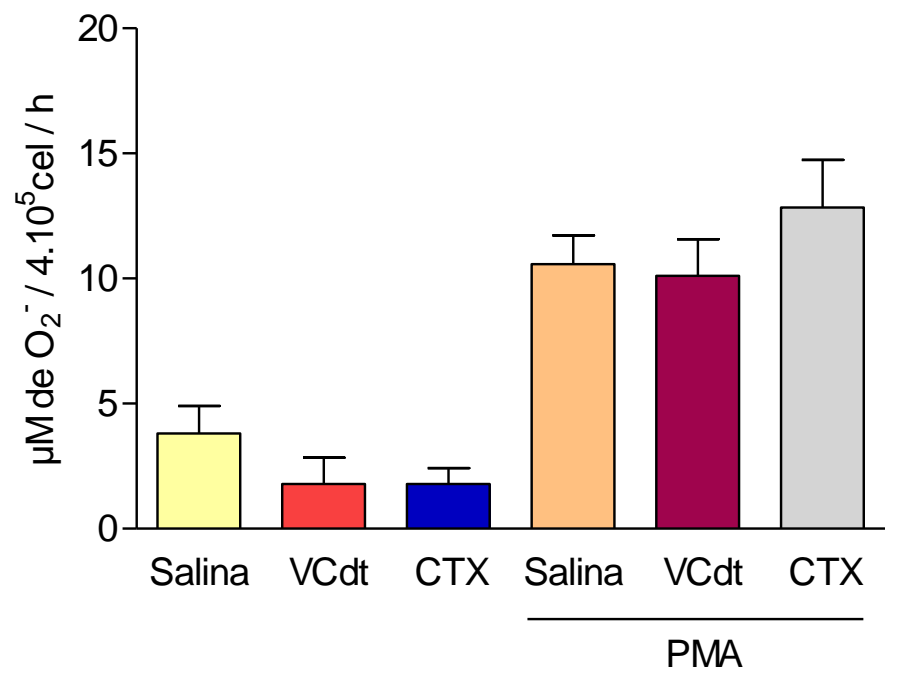

Figura 15. Efeito in vivo do VCdt e da CTX sobre a produção de ânion superóxido por neutrófilos. VCdt $(0,18 \mathrm{mg} / \mathrm{kg}), \mathrm{CTX}(0,1 \mathrm{mg} / \mathrm{kg})$ ou salina estéril (controle) foi injetado pela via subcutânea em ratos, 2 horas antes da administração intraperitoneal de carragenina $(4,5 \mathrm{mg} / \mathrm{kg})$. Após a coleta dos neutrófilos, a produção de ânion superóxido foi avaliada na presença ou na ausência de PMA. Os resultados correspondem à média \pm SEM de 5 animais. 
6. Efeito in vitro e in vivo do VCdt e da Crotoxina sobre a Produção de Peróxido de Hidrogênio por Neutrófilos

A incubação dos neutrófilos com o VCdt $(0,25 ; 0,5$ ou $1,0 \mu \mathrm{g} / \mathrm{mL})$ ou a CTX $(0,02 ; 0,04$ ou $0,08 \mu \mathrm{g} / \mathrm{mL})$, em nenhuma das concentrações avaliadas, alterou a produção de peróxido de hidrogênio por essas células, na presença ou na ausência de PMA, quando comparado aos respectivos grupos controles incubados somente na presença de meio RPMI 1640 (Figura 16).

Da mesma forma, o tratamento dos animais com o VCdt $(0,18 \mathrm{mg} / \mathrm{kg})$ ou a CTX $(0,1 \mathrm{mg} / \mathrm{kg}), 2$ horas antes da administração intraperitoneal de carragenina $(4,5 \mathrm{mg} / \mathrm{kg})$, não alterou a produção de peróxido de hidrogênio por essas células, na presença ou na ausência de PMA, quando comparado aos animais tratados apenas com salina estéril (controle) (Figura 17). 

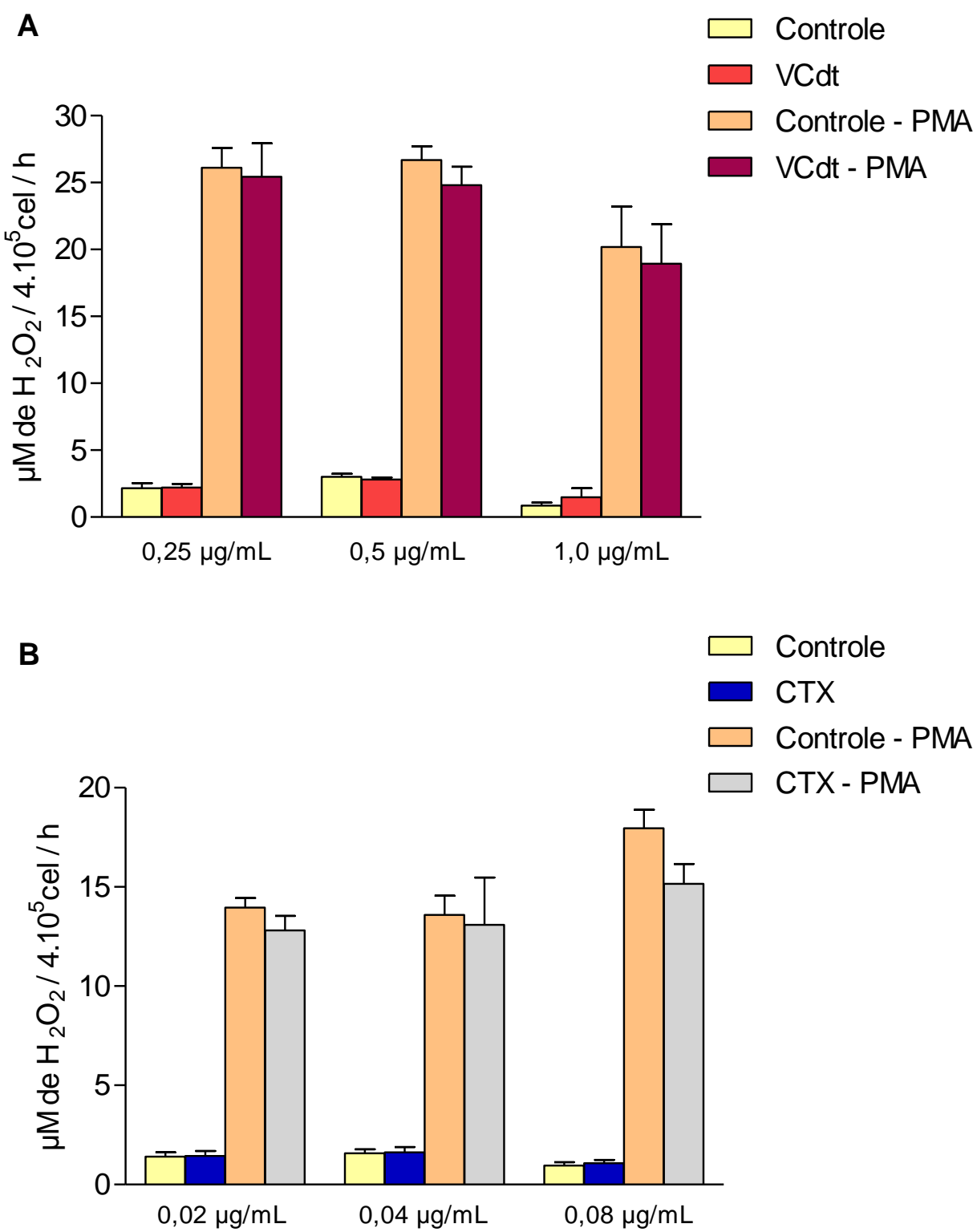

Figura 16. Efeito in vitro do VCdt (A) e da CTX (B) sobre a produção de peróxido de hidrogênio por neutrófilos. Neutrófilos $\left(4 \times 10^{5}\right)$ foram coletados 4 horas após a administração intraperitoneal de carragenina $(4,5 \mathrm{mg} / \mathrm{kg})$ e incubados por 1 hora com diferentes concentrações de VCdt $(0,25 ; 0,5$ e $1,0 \mu \mathrm{g} / \mathrm{mL})$ ou CTX $(0,02 ; 0,04$ e 0,08 $\mu \mathrm{g} / \mathrm{mL})$. Neutrófilos incubados somente na presença de meio RPMI 1640 foram utilizados como controle. Após o período de incubação, a produção de peróxido de hidrogênio foi avaliada na presença ou na ausência de PMA. Os resultados correspondem à média \pm SEM de 10 animais. 


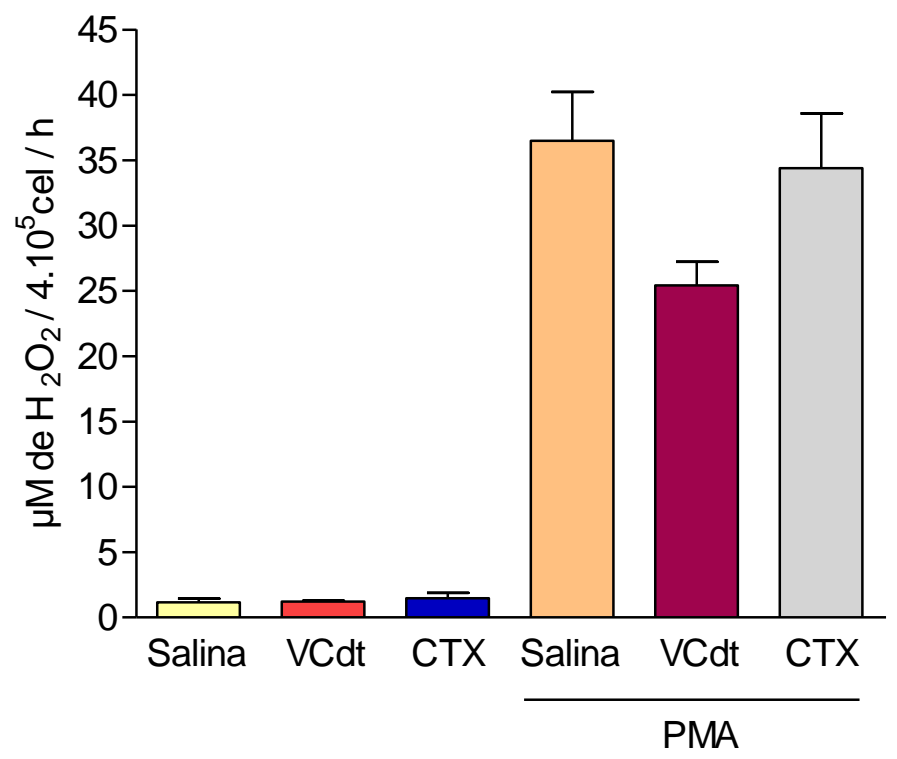

Figura 17. Efeito in vivo do VCdt e da CTX sobre a produção de peróxido de hidrogênio por neutrófilos. VCdt $(0,18 \mathrm{mg} / \mathrm{kg})$, CTX $(0,1 \mathrm{mg} / \mathrm{kg})$ ou salina estéril (controle) foi injetado pela via subcutânea em ratos, 2 horas antes da administração intraperitoneal de carragenina $(4,5 \mathrm{mg} / \mathrm{kg})$. Após a coleta dos neutrófilos, a produção de peróxido de hidrogênio foi avaliada na presença ou na ausência de PMA. Os resultados correspondem à média \pm SEM de 5 animais. 
7. Efeito in vitro e in vivo do VCdt e da Crotoxina sobre a Produção de Ácido Hipocloroso por Neutrófilos

A incubação dos neutrófilos com o VCdt $(0,25 ; 0,5$ ou $1,0 \mu \mathrm{g} / \mathrm{mL})$ ou a CTX $(0,02 ; 0,04$ ou $0,08 \mu \mathrm{g} / \mathrm{mL})$, em nenhuma das concentrações avaliadas, na presença ou na ausência de PMA, alterou a produção de ácido hipocloroso por essas células, quando comparado aos respectivos grupos controles incubados somente na presença de meio RPMI 1640 (Figura 18).

Além disso, o tratamento dos animais com o VCdt $(0,18 \mathrm{mg} / \mathrm{kg})$ ou a CTX $(0,1$ $\mathrm{mg} / \mathrm{kg}), 2$ horas antes da administração intraperitoneal de carragenina (4,5 mg/kg), não alterou a produção de ácido hipocloroso por neutrófilos, na presença ou na ausência de PMA, quando comparado aos animais tratados apenas com salina estéril (controle) (Figura 19). 

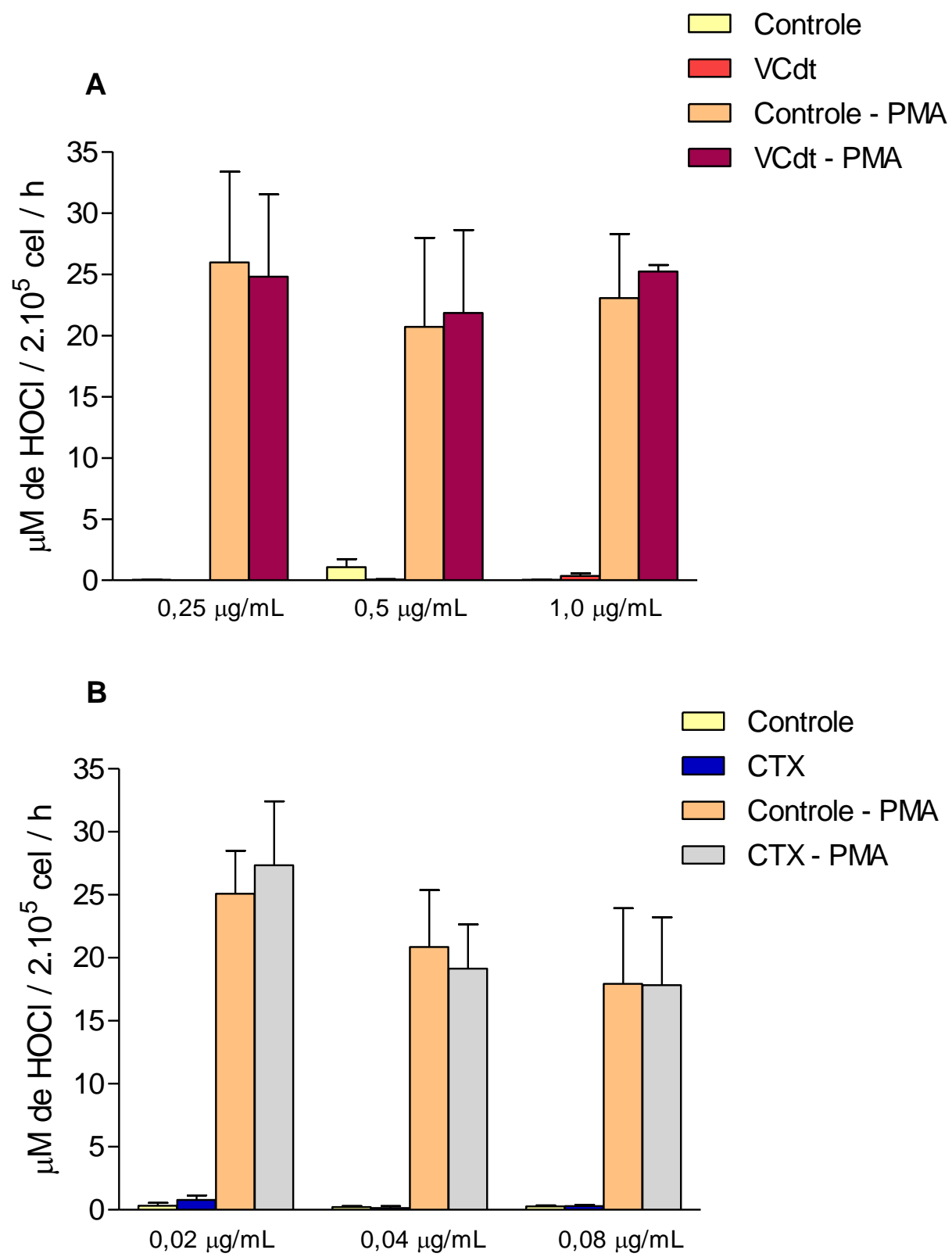

Figura 18. Efeito in vitro do VCdt (A) e da CTX (B) sobre a produção de ácido hipocloroso por neutrófilos. Neutrófilos $\left(2 \times 10^{5}\right)$ foram coletados 4 horas após a administração intraperitoneal de carragenina $(4,5 \mathrm{mg} / \mathrm{kg})$ e incubados por 1 hora com diferentes concentrações de VCdt $(0,25 ; 0,5$ e $1,0 \mu \mathrm{g} / \mathrm{mL})$ ou CTX $(0,02 ; 0,04$ e 0,08 $\mu \mathrm{g} / \mathrm{mL})$. Neutrófilos incubados somente na presença de meio RPMI 1640 foram utilizados como controle. Após o período de incubação, a produção de ácido hipocloroso foi avaliada na presença ou na ausência de PMA. Os resultados correspondem à média \pm SEM de 5 animais. 


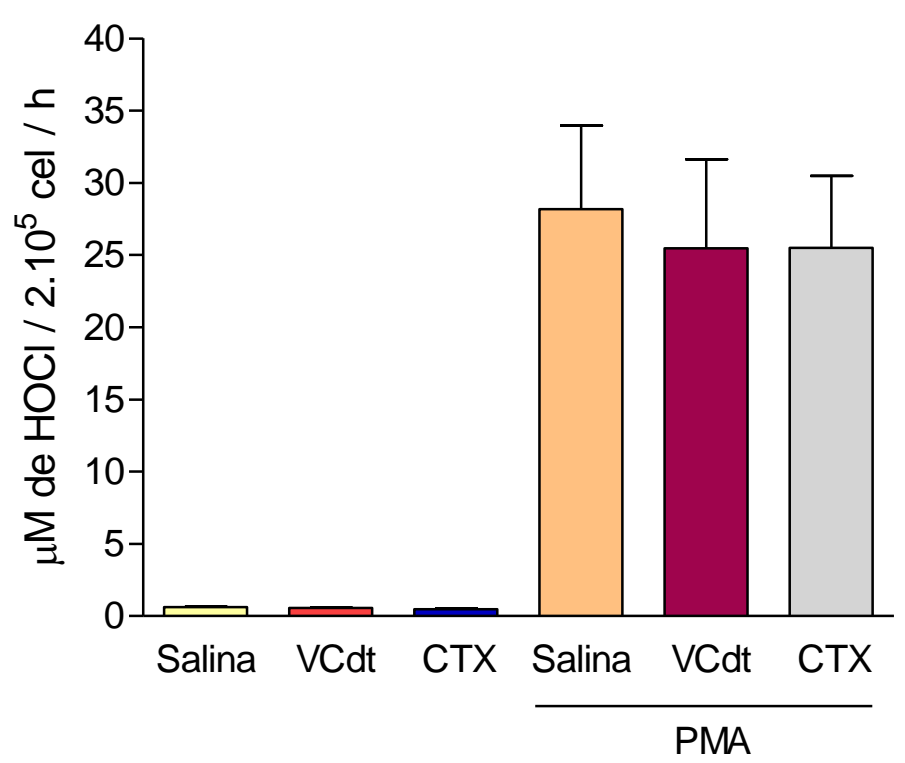

Figura 19. Efeito in vivo do VCdt e da CTX sobre a produção de ácido hipocloroso por neutrófilos. VCdt $(0,18 \mathrm{mg} / \mathrm{kg})$, CTX $(0,1 \mathrm{mg} / \mathrm{kg})$ ou salina estéril (controle) foi injetado pela via subcutânea em ratos, 2 horas antes da administração intraperitoneal de carragenina $(4,5 \mathrm{mg} / \mathrm{kg})$. Após a coleta dos neutrófilos, a produção de ácido hipocloroso foi avaliada na presença ou na ausência de PMA. Os resultados correspondem à média \pm SEM de 5 animais. 
Discussão 


\section{DISCUSSÃO}

Como mencionado na Introdução, várias evidências têm demonstrado que o VCdt ou suas toxinas isoladas são capazes de modular a resposta inflamatória. A literatura relata que a resposta inflamatória induzida pela carragenina nas cavidades pleural e peritoneal é caracterizada por um intenso exsudato e migração de células inflamatórias, particularmente de neutrófilos. Esse aumento da migração de células para a cavidade peritoneal ocorre 4 horas após a injeção intraperitoneal de carragenina. (Vinegar et al., 1973; Malech \& Gallin, 1987; Gill et al., 2006).

Os neutrófilos são células essenciais ao sistema de defesa inata do organismo, uma vez que são as primeiras células a chegarem ao foco inflamatório, onde realizam a fagocitose e a destruição de agentes lesivos (Kobayashi et al., 2003; Lee et al., 2003). Sendo assim, dada a importância dos neutrófilos para a resposta inflamatória, recentemente, foi demonstrado que o $\mathrm{VCdt}$, in vitro $e$ in vivo, inibe a fagocitose mediada por $\mathrm{C} 3 \mathrm{~b} / \mathrm{C} 3$ bi, por neutrófilos obtidos no modelo de peritonite induzido pela carragenina, em ratos (Lima et al., 2007).

Dessa forma, dando continuidade a essa linha de investigação, no presente estudo, inicialmente foi investigado qual o componente do VCdt é responsável por seu efeito inibitório sobre o processo de fagocitose por neutrófilos. Além disso, foram analisados os possíveis mecanismos de ação envolvidos nesse efeito inibitório, avaliando a fosforilação de resíduos de tirosina e polimerização de actina nos fagossomas; bem como o efeito do VCdt e da CTX sobre a atividade microbicida, outra função importante dos neutrófilos.

Para a identificação do componente do VCdt anteriormente mencionado, foi analisada a ação in vitro da CTX purificada (pico II) e dos demais picos, I e III, obtidos 
através do processo de purificação da CTX. Os resultados mostraram que a CTX $(0,02$; 0,$04 ; 0,08 ; 0,16$ ou $0,32 \mu \mathrm{g} / \mathrm{mL}$ ) inibiu a atividade fagocítica dessas células, porém o mesmo efeito não foi observado para os picos I e III. Esses resultados demonstram que CTX é o componente do VCdt responsável pelo efeito inibitório sobre a fagocitose por neutrófilos, o que reforça outros resultados encontrados na literatura. Esses evidenciam a CTX como sendo o componente responsável pelo efeito inibitório do VCdt sobre a fagocitose por macrófagos (Sampaio et al., 2003) e pela ação antiinflamatória do VCdt (Nunes et al., 2010).

Uma vez determinado o efeito in vitro da CTX, foi investigado a seguir o seu efeito in vivo sobre a atividade fagocítica de neutrófilos. Cabe esclarecer que a dose de CTX administrada pela via subcutânea nos animais $(0,1 \mathrm{mg} / \mathrm{kg})$ correspondeu a $60 \%$ da dose de VCdt bruto, dose esta que induz o efeito inibitório sobre a atividade fagocítica de macrófagos e neutrófilos (Sampaio et al.,2003; Lima et al., 2007). Os resultados do estudo in vivo mostraram que a CTX, além do efeito direto sobre os neutrófilos, apresenta efeito sistêmico, uma vez que o pré-tratamento dos animais 2 horas, 1, 4 ou 14 dias antes da administração do agente inflamatório induziu o mesmo efeito inibitório observado in vitro. Esses dados mostram que a CTX apresenta um efeito inibitório prolongado sobre a atividade fagocítica dos neutrófilos, já que este foi observado até 14 dias depois da administração de uma única dose, tal como observado para o VCdt total (Lima et al., 2007). Este mesmo efeito inibitório prolongado do VCdt também foi demonstrado para o espraiamento e para a atividade fagocítica de macrófagos (Sousa-eSilva et al., 1996). Além disso, Nunes e col. (2007) mostraram que o VCdt apresenta ação antiinflamatória prolongada, uma vez que uma única dose, administrada pela via subcutânea, 7 ou 21 dias antes da injeção de carragenina inibe, respectivamente, o 
desenvolvimento do edema de pata e a migração celular para a cavidade peritoneal induzidos por este agente inflamatório.

Estudos de biodistribuição demostraram que o VCdt permanece no tecido subcutâneo por até 6 horas, entretanto, 4 horas após sua administração, já não é mais detectado em órgãos como rins, baço e cérebro (Gomes et al., 2002). Baseado neste fato, é difícil explicar como uma única dose de VCdt ou de CTX permanece, por um longo período de tempo, agindo sobre a resposta inflamatória e sobre as funções de macrófagos e neutrófilos (Sousa-e-Silva et al., 1996; Nunes et al., 2007; 2010; Lima et $a l ., 2007)$.

Os neutrófilos e os macrófagos originam-se de um precursor comum, stem cell, o qual se diferencia em progenitores mielóides e a seguir em progenitores das linhagens granulocítica e monocítica (Bradley \& Metcalf, 1966; Metcalf, 1989). Dessa forma, podemos sugerir que o efeito prolongado induzido pela CTX sobre a fagocitose por macrófagos e neutrófilos pode estar associado à ação desta toxina sobre células precursoras presentes na medula óssea. Entretanto, estudos futuros deverão ser realizados para comprovar essa hipótese.

Adicionalmente, os dados obtidos nos ensaios in vivo mostraram também que a CTX inibe a atividade fagocítica de neutrófilos, mesmo após a instalação da resposta inflamatória, uma vez que essa inibição foi observada quando esta toxina foi administrada 1 hora após a injeção do estímulo inflamatório.

Em relação ao efeito inibitório da CTX in vivo, a possível liberação de mediadores químicos endógenos induzida por essa toxina deve ser considerada. Nesse contexto, Sampaio e col. (2006a) mostraram que o efeito inibitório da CTX sobre a funcionalidade de macrófagos, tanto em ensaios in vivo como in vitro, é decorrente da ação de mediadores lipídicos derivados da via das lipoxigenases. Além disso, a CTX 
estimula a liberação de lipoxina $\mathrm{A}_{4}$ e prostaglandina $\mathrm{E}_{2}$ por macrófagos (Sampaio et al., 2006a). A lipoxina, um eicosanóide produzido na via da lipoxigenase, é um mediador com ação antiinflamatória que se liga a receptores FPR2/ALX (receptor formil peptídeo 2) para desempenhar suas funções biológicas (Maderna \& Godson, 2009; Ryan \& Godson, 2010).

Ainda, evidenciado o papel da lipoxina no efeito modulador da CTX na resposta inflamatória, estudos recentes que caracterizam o efeito antiinflamatório da CTX demonstraram o envolvimento dos receptores formil peptídeo, como FPR2/ALX nesse efeito. Assim, podemos sugerir que a liberação de lipoxina por macrófagos poderia modular a atividade fagocítica dos neutrófilos já que existem evidências de que a lipoxina reduz a expressão de receptores CR3 (CD11b/CD18) em neutrófilos (Maderna \& Godson, 2009). Essa hipótese pode ser considerada, uma vez que estes fagócitos possuem características complementares e cooperam como efetores e moduladores da resposta imune (Silva, 2010).

Durante a fagocitose mediada pelos receptores CR1/CR3, a ligação de partículas opsonizadas por fragmentos do sistema complemento (C3b/ C3bi) a estes receptores ativa as vias de sinalização intracelular envolvidas nessa resposta. Essa ativação leva ao rearranjo organizado do citoesqueleto da célula, com polimerização da actina para a formação dos fagossomas e, consequente, englobamento da partícula (Fenteany \& Glogauer, 2004). A fosforilação da tirosina, ou seja, a adição de fosfato aos resíduos de tirosina, é um evento importante nesta sinalização, uma vez que converte simples proteínas em transdutores de sinais ativos que garantem a polimerização da actina e a fagocitose (Walzog et al., 1996).

Nesse sentido, com o intuito de verificar um dos possíveis mecanismos envolvidos na ação inibitória do VCdt e da CTX, foram investigados os efeitos in vitro 
e in vivo dessas toxinas, sobre a fosforilação de resíduos de tirosina e a polimerização de actina, em fagossomas nascentes e maduros. Os resultados mostraram que o VCdt ou a CTX, tanto in vitro como in vivo, inibiram intensamente a fosforilação de tirosina e a polimerização de actina nos neutrófilos submetidos ao ensaio de fagocitose por cinco minutos (fagossoma nascente). Entretanto, em neutrófilos submetidos ao ensaio de fagocitose por 15 minutos, ou seja, em fagossomas maduros, não foi possível observar a fosforilação de tirosina em células incubadas somente com meio RPMI 1640, uma vez que a sinalização intracelular ocorre de maneira bastante rápida (Dharmawardhane $e t$ al., 1999; Minakami et al., 2010). Levando em conta esse fato, em fagossomas maduros, só foi possível avaliar o efeito in vitro do VCdt e da CTX sobre os filamentos de actina. As análises mostraram que a CTX inibe também a polimerização de actina nos fagossomas maduros. Por outro lado, estudos anteriores demonstraram que em macrófagos a CTX aumenta a polimerização de actina no processo de fagocitose (Sampaio et al., 2006b).

Em relação ao processo de polimerização da actina durante a fagocitose, a literatura relata que algumas toxinas naturais têm como alvo proteínas do citoesqueleto, o que altera o processo natural de polimerização e despolimerização dos filamentos comprometendo as funções de adesão, migração e fagocitose das células (Alberts et al., 2002). Nesse sentido, Ernst e col. (2000) demonstraram que toxinas de espécies de Clostridium, tais como $C$. botulinum e $C$. difficile, inativam proteínas de sinalização da família Rho das GTPases e desta maneira interferem no mecanismo de polimerização de actina.

A proteína Rho, pertencente à família das Rho GTPases desempenha importante papel na fagocitose mediada por receptores CR3, uma vez que garante a polimerização de actina nas regiões dos fagossomas e o consequente englobamento da partícula 
(Caron \& Hall, 1998; Chimini \& Chavrier, 2000; Le Cabec et al., 2002). A sua ativação é regulada por outras proteínas que são fosforiladas e ativadas durante a cascata de sinalização. Shi e col. (2006) demonstraram a participação da proteína tirosina quinase Syk na fagocitose de partículas de zimosan opsonizadas com fragmentos C3bi do complemento por células HL-60, precursoras de neutrófilos e, ainda, o papel regulador dessa proteína sobre a atividade de RhoA.

Considerando a importância de proteínas sinalizadoras para o processo de fagocitose, podemos sugerir que a inibição da fosforilação induzida pela CTX pode levar a mudanças na ativação dessas proteínas sinalizadoras e a consequente redução da polimerização de actina. Corroboram a essa hipótese estudos anteriores que mostraram que o efeito inibitório do CTX sobre o processo de fagocitose por macrófagos está associado ao decréscimo da RhoA e Rac1 (Sampaio et al., 2006b). Apesar dessas evidências, futuros estudos devem ser realizados para ampliar a compreensão dos mecanismos intracelulares envolvidos no efeito inibitório da CTX sobre o processo de fagocitose por neutrófilos, levando em conta as diferenças entre as vias de sinalização envolvidas no processo de fagocitose por neutrófilos e por macrófagos (Forsberg et al. 2003).

O processo de fagocitose resulta na liberação de enzimas com ação microbicida, contidas nos grânulos citoplasmáticos dos neutrófilos, bem como na ativação da enzima NADPH oxidase, o que leva a geração de espécies reativas do oxigênio (Faurschou \& Borregaard, 2003; Klebanoff, 2005). Nesse sentido, no presente estudo, foi avaliado o efeito in vitro e in vivo do VCdt e da CTX sobre a atividade microbicida de neutrófilos, utilizando-se os mesmos tratamentos realizados nos ensaios de fagocitose. Os resultados mostraram que o VCdt e a CTX, in vitro e in vivo, nas mesmas condições avaliadas para a fagocitose, não alteraram a atividade microbicida de 
Candida albicans por neutrófilos. Esses resultados indicam que o VCdt e a CTX não têm efeito sobre a atividade microbicida de neutrófilos, o que difere de estudos prévios, os quais demonstram que o VCdt estimula essa atividade em macrófagos (Sampaio et al., 2001).

Com o intuito de comprovar os dados obtidos nos ensaios de atividade microbicida foram avaliados os efeitos in vitro e in vivo do VCdt e da CTX sobre a produção de ânion superóxido, peróxido de hidrogênio e ácido hipocloroso induzida pelo PMA, uma vez que a literatura relata a utilização de metodologias que quantificam a produção dessas espécies reativas do oxigênio induzida pelo PMA para a avaliação da atividade microbicida de macrófagos e neutrófilos (Pick \& Mizel, 1981; Dypbukt et al., 2005; Winterbourn, et al. 2006.).

Assim como nos ensaios de atividade microbicida de Candida albicans, os tratamentos in vitro e in vivo com o VCdt ou a CTX não alteraram a produção de espécies reativas do oxigênio por neutrófilos, tanto na presença quanto na ausência de PMA.

Apesar da associação existente entre o processo de fagocitose e a atividade microbicida, algumas considerações em relação às vias de sinalização envolvidas em ambos os processos devem ser consideradas, pois diferem em alguns pontos. Como citado anteriormente, a proteína Rho tem um papel significante na regulação da polimerização de actina para a fagocitose mediada por receptores CR1/CR3 (Caron \& Hall, 1998; Chimini \& Chavrier, 2000; Le Cabec et al., 2002), porém não atua na ativação da enzima NADPH oxidase em resposta ao PMA ( Kim et al., 2004). Por outro lado, tem sido mostrada a participação da Rac2, outra proteína da família das Rho GTPases, na ativação da NADPH oxidase em resposta a esse agente (Ambruso et al., 2000; Werner, 2004; Abdel-Latif at al., 2005). 
Dessa forma, baseado nas considerações a cima, uma hipótese que poderia explicar o efeito inibitório da CTX, particularmente sobre a fagocitose, seriam as diferenças existentes entre as vias de sinalização envolvidas na fagocitose e na geração de espécies reativas do oxigênio.

Em conjunto, os resultados deste estudo caracterizam as ações do VCdt sobre os neutrófilos, evidenciando que a CTX, seu principal componente, modula a funcionalidade dessas células, inibindo, in vitro e in vivo, a fosforilação de proteínas sinalizadoras e a polimerização de actina no processo de fagocitose, porém não altera a atividade microbicida e a produção de espécies reativas do oxigênio por neutrófilos.

Dessa forma, este estudo amplia os conhecimentos das ações moduladoras da CTX sobre a resposta inflamatória e, ainda, contribui para a elucidação dos mecanismos envolvidos nestas ações, particularmente, sobre a inibição do processo de fagocitose por neutrófilos. Além disso, os dados evidenciam mais uma vez que esta toxina apresenta importante potencial como ferramenta científica para a compreensão dos mecanismos envolvidos na fisiopatologia da resposta inflamatória, bem como pode representar uma nova perspectiva no controle de doenças inflamatórias. 
Resumo dos Resultados 


\section{RESUMO DOS RESULTADOS}

A incubação dos neutrófilos com diferentes concentrações de CTX $(0,02 ; 0,04 ; 0,08$; 0,16 ou $0,32 \mu \mathrm{g} / \mathrm{mL}$ ) inibiu a atividade fagocítica dessas células.

Por outro lado, a incubação dos neutrófilos com diferentes concentrações dos picos I ou II $(0,02 ; 0,04 ; 0,08 ; 0,16$ ou $0,32 \mu \mathrm{g} / \mathrm{mL})$, obtidos durante a purificação da CTX, não alterou a fagocitose por essas células.

A administração de uma única dose de CTX pela via subcutânea nos animais, 2 horas, 1, 4 ou 14 dias antes ou 1 hora após a administração de carragenina, inibiu a atividade fagocítica dos neutrófilos desses animais.

A incubação dos neutrófilos com o VCdt $(0,5 \mu \mathrm{g} / \mathrm{mL})$ ou a CTX $(0,08 \mu \mathrm{g} / \mathrm{mL})$ reduziu significativamente a fosforilação de resíduos de tirosina e a polimerização de actina em fagossomas nascentes.

A administração pela via subcutânea de VCdt $(0,18 \mathrm{mg} / \mathrm{kg})$ ou CTX $(0,1 \mathrm{mg} / \mathrm{kg}), 2$ horas antes da administração de carragenina, inibiu a fosforilação de resíduos de tirosina e a polimerização de actina em fagossomas nascentes.

A incubação dos neutrófilos com diferentes concentrações de VCdt $(0,125 ; 0,25 ; 0,5$; $1,0$ ou $2,0 \mu \mathrm{g} / \mathrm{mL})$ ou $\operatorname{CTX}(0,02 ; 0,04 ; 0,08 ; 0,16$ ou $0,32 \mu \mathrm{g} / \mathrm{mL})$ não alterou a atividade microbicida de Candida albicans por essas células. 
O tratamento dos animais com o VCdt $(0,18 \mathrm{mg} / \mathrm{kg})$ ou a CTX $(0,1 \mathrm{mg} / \mathrm{kg}), 2$ horas antes da administração de carragenina, não modificou a atividade microbicida de Candida albicans por neutrófilos.

A incubação dos neutrófilos com diferentes concentrações de VCdt $(0,25 ; 0,5$ ou 1,0 $\mu \mathrm{g} / \mathrm{mL})$ ou CTX $(0,02 ; 0,04$ ou $0,08 \mu \mathrm{g} / \mathrm{mL})$ não alterou a produção de ânion superóxido, peróxido de hidrogênio e ácido hipocloroso por essas células.

O tratamento dos animais com o VCdt $(0,18 \mathrm{mg} / \mathrm{kg})$ ou a CTX $(0,1 \mathrm{mg} / \mathrm{kg}), 2$ horas antes da administração de carragenina, não modificou a produção de ânion superóxido, peróxido de hidrogênio e ácido hipocloroso por neutrófilos. 


\section{Conclusão}




\section{CONCLUSÃO}

Os resultados obtidos nesse estudo permitem concluir que a CTX é o componente do VCdt responsável por inibir a fagocitose por neutrófilos, e que este efeito está relacionado ao decréscimo da fosforilação de proteínas sinalizadoras e a consequente diminuição da polimerização dos filamentos de actina nos fagossomas, o que impede a completa internalização da partícula. Por outro lado, os dados evidenciam que o VCdt e a CTX não alteram a atividade microbicida e a produção de ânion superóxido, peróxido de hidrogênio e ácido hipocloroso por neutrófilos. 
Resumo 


\section{RESUMO}

Estudos anteriores demonstraram que o veneno de Crotalus durissus terrificus (VCdt) apresenta ação antiinflamatória prolongada, bem como inibe o espraiamento e a atividade fagocítica de macrófagos peritoneais, sendo a crotoxina (CTX), o principal componente do VCdt, a responsável por esses efeitos. Em relação aos neutrófilos, demonstrou-se que o VCdt inibe, in vitro e in vivo, a fagocitose por essas células, porém o componente do VCdt responsável por esse efeito não foi identificado. Dessa forma, o objetivo desse estudo foi identificar o componente responsável pelo efeito inibitório do VCdt sobre a fagocitose por neutrófilos, bem como investigar os possíveis mecanismos envolvidos nessa ação. Além disso, foi também objetivo desse estudo investigar o efeito do VCdt e da CTX sobre a atividade microbicida e a produção de espécies reativas do oxigênio por essas células. Inicialmente, foi avaliado o efeito in vitro dos três picos do VCdt, obtidos durante a purificação da CTX (pico I; pico II, que corresponde a CTX, e pico III), sobre a atividade fagocítica de neutrófilos. A incubação dos neutrófilos com a CTX ou com os picos I ou III, em diferentes concentrações $(0,02 ; 0,04 ; 0,08 ; 0,16$ ou $0,32 \mu \mathrm{g} / \mathrm{mL})$, mostrou que somente o pico II inibiu essa atividade, demonstrando que a CTX é o componente do VCdt responsável pelo seu efeito inibitório sobre a fagocitose por neutrófilos. Uma vez realizada essa identificação, foi investigado o efeito in vivo da CTX sobre essa função. O tratamento dos animais com a CTX $(0,1 \mathrm{mg} / \mathrm{kg}), 2$ horas, 1,4 ou 14 dias antes ou 1 hora após a administração de carragenina inibiu a fagocitose por neutrófilos, o que demonstra que esta toxina, além do efeito direto, apresenta efeito sistêmico sobre a atividade fagocítica dessas células. Esses resultados mostraram também que a CTX apresenta efeito inibitório prolongado sobre a atividade fagocítica de neutrófilos. Ainda, com o objetivo de elucidar os possíveis mecanismos envolvidos nesse efeito inibitório foram realizados ensaios imunocitoquímicos para avaliar a reorganização do citoesqueleto. A incubação dos neutrófilos com o VCdt $(0,5 \mu \mathrm{g} / \mathrm{mL})$ ou com a CTX $(0,08 \mu \mathrm{g} / \mathrm{mL})$, bem como o tratamento dos animais com o VCdt $(0,18 \mathrm{mg} / \mathrm{kg})$ ou a CTX $(0,1 \mathrm{mg} / \mathrm{kg}), 2$ horas antes da administração de carragenina, inibiram a fosforilação de resíduos de tirosina e a polimerização da actina. Em relação ao efeito do VCdt e da CTX sobre outra função dos neutrófilos, foi investigado, em ensaios in vitro e in vivo, a atividade microbicida e a produção de espécies reativas do oxigênio por essas células. A incubação dos neutrófilos com o VCdt $(0,125 ; 0,25$; $0,5 ; 1,0$ ou $2,0 \mu \mathrm{g} / \mathrm{mL})$ ou a CTX $(0,02 ; 0,04 ; 0,08 ; 0,16$ ou $0,32 \mu \mathrm{g} / \mathrm{mL})$, bem como o tratamento dos animais com o VCdt $(0,18 \mathrm{mg} / \mathrm{kg})$ ou a CTX $(0,1 \mathrm{mg} / \mathrm{kg}), 2$ horas antes da administração de carragenina, não alteraram a atividade microbicida e a produção de ânion superóxido, peróxido de hidrogênio e ácido hipocloroso. Em conclusão, a CTX é o componente do VCdt responsável por inibir a fagocitose por neutrófilos e um dos mecanismos envolvidos neste efeito é a inibição da fosforilação de proteínas sinalizadoras e a conseqüente polimerização de actina, importante evento para o início da formação do fagossoma e a completa internalização da partícula. Por outro lado, o VCdt e a CTX não alteram a atividade microbicida e a produção de espécies reativas do oxigênio por neutrófilos. Dessa forma, considerando-se o papel fundamental dessas células na inflamação, este estudo amplia os conhecimentos das ações moduladoras da CTX sobre a resposta inflamatória e, ainda, contribui para a elucidação dos mecanismos envolvidos nestas ações, particularmente, a inibição do processo de fagocitose por neutrófilos.

Palavras-chave: Crotalus durissus terrificus, crotoxina, inflamação, neutrófilo, fagocitose, atividade microbicida. 
Abstract 


\section{ABSTRACT}

Previous studies showed that Crotalus durissus terrificus snake venom (CdtV) has longlasting anti-inflammatory properties and inhibits the spreading and the phagocytic activity of peritoneal macrophages. Crotoxin (CTX), the main component of $\mathrm{CdtV}$, is responsible for these effects. In addition, CdtV inhibits, in vitro and in vivo, the phagocytic activity of neutrophils, but the component of the venom responsible for this effect was not identified. In this way, the aim of this study was to investigate the $\mathrm{CdtV}$ component responsible for the inhibitory effect on phagocytosis by neutrophils, as well as to investigate possible mechanisms involved on this effect. Besides, the aim of this study was also to investigate the effect of CdtV and CTX on the microbicidal activity and the production of reactive oxygen species by neutrophils. Initialy, it was avaliated the in vitro effect of the three peaks of $\mathrm{CdtV}$, obtained during CTX purification (peak I, peak II that corresponds to CTX and peak III), on phagocytosis by neutrophils. The incubation of the cells with CTX, peak I or peak III, at different concentrations $(0.02,0.04$, $0.08,0.16$ or $0.32 \mu \mathrm{g} / \mathrm{mL}$ ), showed that just peak II inhibited this activity, so CTX is the CdtV component responsible for the inhibitory effect on phagocytosis by neutrophils. Once realized this identification, it was investigated the in vivo effect of CTX on the same neutrophil function. Treating animals with CTX $(0.1 \mathrm{mg} / \mathrm{kg}), 2$ hours, 1,4 or 14 days before or 1 hour after the administration of carrageenan inhibited the phagocytic activity of neutrophils, which demonstrates that this toxin, in addition to the direct effect, has systemic effect on phagocytosis by neutrophils. These results also show that CTX has a long-lasting inhibitory effect on the phagocytic activity of these cells. Further, to elucidate possible mechanisms involved on this inhibitoty effect, immunocytochemical assays was realized to evaluate the reorganization of the cytoskeleton. The incubation of the neutrophils with CdtV $(0.5 \mu \mathrm{g} / \mathrm{mL})$ or CTX $(0.08 \mu \mathrm{g} / \mathrm{mL})$, as well as the treatment of the animals with CdtV $(0.18 \mathrm{mg} / \mathrm{kg})$ or CTX $(0.1 \mathrm{mg} / \mathrm{kg}), 2$ hours before the carrageenan injection, inhibited the phosphorilation of tyrosine residues and actin polymerization. Regarding the effect of $\mathrm{CdtV}$ and CTX in other neutrophil function, it was investigated, in vitro and in vivo, the microbicidal activity and the production of reactive oxygen species by neutrophils. The incubation of the cells with $\mathrm{CdtV}(0.125,0.25,0.5,1.0$ or $2.0 \mu \mathrm{g} / \mathrm{mL})$ or CTX $(0.02,0.04,0.08,0.16$ or $0.32 \mu \mathrm{g} / \mathrm{mL})$, as well as the treatment of the animals with CdtV $(0.18 \mathrm{mg} / \mathrm{kg})$ or CTX $(0.1 \mathrm{mg} / \mathrm{kg}), 2$ hours before the carragennan injection, did not alter the microbicidal activity or the production of superoxide, hydrogen peroxide and hypochlorous acid. In conclusion, CTX is the $\mathrm{CdtV}$ component responsible for the inhibitory effect on phagocytosis by neutrophils and a mechanism involved on this effect is the inhibition of phosphorilation of signaling proteins and the consequent actin polymerization, an important event for the phagosome formation and the complete internalization of the particle. On the other hand, CdtV and CTX did not alter the microbicidal activity or the production of reactive oxygen species. Thus, considering the essential role of these cells in inflammation, this study extends the knowledge of the actions of CTX on modulating the inflammatory response and also contributes to the elucidation of the mechanisms involved in these actions, particularly the inhibition of phagocytosis by neutrophils.

Key-words: Crotalus durissus terrificus, crotoxin, inflammation, neutrophil, phagocytosis, microbicidal activity. 
Referências Bibliográficas 


\section{REFERÊNCIAS BIBLIOGRÁFICAS}

ABDEL-LATIF, D.; STEWARS, M.; LACY, P. Neutrophil primary granule release and maximal superoxide generation depend on Rac2 in a common signaling pathway. Can J Physiol Pharmacol, v.83, n.1, p.69-75, 2005.

ALBERTS, B.; JOHNSON, A.; LEWIS, J.; RAFF, M.; ROBERTS, K.; WALTER, P. The cytoskeleton. In: Molecular biology of the cell. United States of America, Garland Science, p.907-928, 2002.

ALLEN, L.A. Imunofluorescence and confocal microscopy of neutrophils. Methods Mol Biol, v.412, p.273-87, 2007.

AMARAL, C.F.S.; MAGALHÃES, R.A.; REZENDE, N.A. Comprometimento respiratório secundário a acidente (Crotalus durissus). Rev Inst Med Trop São Paulo, v.33, n.4, p.251-255, 1991.

AMBRUSO, D.R.; KNALL, C.; ABELL, A.N.; PANEPINTO, J.; KURKCHUBASCHE, A.; THURMAN, G.; GONZALEZ-ALLER, C.; HIESTER, A.; DE BOER, M.; HARBECK, R.J.; OYER, R.; JOHNSON, G.L.; ROOS, D. Human neutrophil immunodeficiency syndrome is associated with an inhibitory Rac2 mutation. Proc Nati Acad Sci USA, v.97, n.9, p.4654-4659, 2000.

AMORIM, M.F.; FRANCO DE MELLO, R.; SALIBA, F. Envenenamento botrópico e crotálico. Mem Inst Butantan, v.23, p.108, 1951.

ARAÚJO, F.A.A.; SANTALÚCIA, M.; CABRAL, R.F. Epidemiologia dos acidentes por animais peçonhentos. In: CARDOSO, J.L.C.; FRANÇA, F.O.S.; WEN, J.H.; MÁLAQUE, C.M.S.; HADDAD JR., V. Acidentes peçonhentos no Brasil biologia, clínica e terapêutica dos acidentes. São Paulo, Editora Sarvier, p.6-12, 2003.

AUGER, M.J.; ROSS, J.A. The biology of the macrophage. In: LEWIS, C.E.; MCGEE, J.O.D. The natural immune system the macrophage. Oxford, IRL press, p.374, 1992.

AXLINE, S.G.; REAVEN, E.P. Inhibition of phagocytosis and plasma 
membrane mobility of the cultivated macrophage by cytochalasin B. Role of subplasmalemmal microfilaments. J Cell Biol, v.62, p.647-659, 1974.

AZEVEDO-MARQUES, M.M.; CUPO, P.; COIMBRA, T.M.; HERING, S.E.; ROSSI, M.A.; LAURE, C.J. Myonecrosis myoglobinuria and acute renal failure indice by South American rattlesnake (Crotalus durissus terrificus) envenomation in Brazil. Toxicon, v.23, n.4, p.631-636, 1985.

AZEVEDO-MARQUES, M.M.; CUPO, P.; HERING, S.E. Evidence that Crotalus durissus terrificus (South American rattlesnake) envenometion in human causes myolysis rather than hemolysis. Toxicon, v.25, n.11, p.1163-1168, 1987.

AZEVEDO-MARQUES, M.M.; HERING, S.E.; CUPO, P. ACIDENTE CROTÁLICO. IN: CARDOSO, J.L.C.; FRANÇA, F.O.S.; WEN, J.H.; MÁLAQUE, C.M.S.; HADDAD JR.,V. Acidentes peçonhentos no Brasil - biologia, clínica e terapêutica dos acidentes. São Paulo, Editora Sarvier, p.91-98, 2003.

BABIOR, B.M.; LAMBETH, J.D.; NAUSEEF, W. The neutrophil NADPH oxidase. Arch Biochem Biophys,v.397, n.2, p.342-344, 2002.

BARRIO, A. Giroxin, a new neurotoxin of Crotalus durissus terrificus venom. Acta Physiol Latinoamericana, v.11, p.24, 1961.

BERGER, M.; WETZLER, E.M.; WALLIS, R.S. Tumor necrosis factor is the major monocyte product that increases complement receptor expression on mature human neutrophils. Blood, v.71, p.151, 1988.

BERTINO, J.R.; SILBER, R. Biochemistry and funtion of granulocytes. In: WILLIAMS, W.J.; BEUTLER, E.; ERSLEV, A.J.; RUNDLES. Hematology, Blakiston, p.568-573, 1972.

BLAKE, G.J.; RIDKER, P.M. Novel clinical markers of vascular wall inflammation. Cir Res, v.89, n.9, p.763-771, 2001.

BON, C.; CHANGEUX, J.P.; JENG, T.W.; FRANKEL-CONRAT, H. Postsynaptic effects of crotoxin and of its isolated subunits. Eur J Biochem, v.99, n.3, p.471-481, 1979. 
BONNAS, C.; VACHIER, I.; CHAVIS, C; GODARD, P.; BOUSQUET, J.; CHANEZ, P. Lipoxins are potential endogenous anti-inflammatory mediators in asthma. Am J Respir Crit Care Med, v.165, p.1531-1535, 2002.

BORREGAARD，N.; LOLLIKE，K.; KJELDSEN， L.; SENGELOV， H.; BASTHOLM, L.; NIELSEN, M.H.; BAINTON, D.F. Human neutrophil granules and secretory vesicles. Eur J Haematol, v.51, n.4, p.187-198, 1993.

BRADFORD, M.M. A rapid and sensitive method for the quantitation of microgram quantities of protein utilizing the principle of protein-dye binding. Anal Biochem, v.72, p.248-54, 1976.

BRADLEY, T.R.; METCALF, D. The growth of mouse bone marrow cells in vitro. Aust J Biol Med Sci, v.44, n.3, p.287-299, 1966.

CAMPANELLI, D.; MELCHIOR, M.; FU, Y.; NAKATA, M.; SHUMAN, H.; NATHAN, C.; GABAY, J.E. Clonig of cDNA for proteinase 3: a serine protease, antibiotic and autoantigen from human neutrophils. J Exp Med, v.172, p.1709-1715, 1990.

CAMPBELL, J.M.; CAMPBELL, J. Absorbância e sua relação com a absorção molar. In: CAMPBELL, J. Matemática de Laboratório - Aplicações Médicas e Biológicas. Editora Roca, $3^{\text {a }}$ edição, p.148-9, 1986.

CARMAN, C.V.; SPRINGER, T.A. A transmigratory cup in leukocyte both through individual vascular endotelial cells and between them. J Cell Biol, v.167, n.2, p.377-388, 2004.

CARON, E.; HALL, A. Identification of two distinct mechanisms of phagocytosis controlled by different Rho GTPases. Science, v. 282, n.5394, p.1717$1721,1998$.

CHIMINI, G.; CHAVRIER, O. Function of Rho family proteins in actin dynamics during phagocytosis and engulfment. Nat Cell Biol, v.2, n.10, p.191-196, 2000. 
CHOUMET, V.; BOUCHIER, C.; DÉLOT, E.; FAURE, G.; SALIOU, B.; BON, C. Structure and function relationship of crotoxin, a heterodimeric neurotoxic phospholipase $\mathrm{A}_{2}$ from the venom of a South-American rattlesnake. Adv Exp Med Biol, v.391, p.197-202, 1996.

CORAZZINI, R. Avaliação morfofisiológica de macrófagos peritoneais de camundongos submetidos ao choque elétrico. 156p. Tese de mestrado em Patologia Experimental e Comparada, Faculdade de Medicina Veterinária e Zootecnia, Universidade de São Paulo, 1993.

CROWLEY, S.R. The pathogenesis of septic chock. Heart Lung, v.25, p.124136, 1996.

CUPO, P.; AZEVEDO-MARQUES, M.M.; HERING, S.E. Clinical and laboratory features of South American rattlesnake (Crotalus durissus terrificus) envenomation in children. Trans R Soc Trop.Med Hyg, v.82, n.6, p.924-929, 1988.

DAHER, K.A.; SELSTED, M.E.; LEHER, R.I. Direct inactivation of viruses by human granulocyte defensins. J Virol, v.60, p.1068-1074, 1986.

DE LEO, F.R.; QUINN, M.T. Assembly of the phagocyte NADPH oxidase: molecular interaction of oxidase proteins. J Leokoc Biol, v.60, n.6, 1996.

DHARMAWARDHANE, S.; BROWNSON, D.; LENNARTZ, M.; BOKOCH, G.M. Localization of p21-activated kinase 1 (PAK1) to pseudopodia, membrane ruffles, and phagocytic cups in activated human neutrophils. $J$ Leukoc Biol, v.66, n.3, p.521$527,1999$.

DYPBUKT, J.M.; BISHOP, C.; BROOKS, W.M.; THONG, B.; ERIKSSON, H.; KETTLE, A.J. A sensitive and selective assay for chloramine production by myeloperoxidase. Free Radic Biol Med, v.39, p.1468-77, 2005.

ENGELHARDT, B.; WOLBURG, H. Transendothelial migration of leukocytes: through the front door or around the side of the house? Eur J Immunol, v.34, n.11, p.2955-2963, 2004. 
ERNST, J.D. Bacterial inhibition of phagocytosis. Cell Microbiol, v.2, n.5, p.379-386, 2000.

FAURSCHOU, M.; BORREGAARD, N. Neutrophil granules and secretory vesicles in inflammation. Microbes Infect, v.5, n.14, p.1317-1327, 2003.

FENTEANY, G.; GLOGAUER, M. Cytoskeletal remodeling in leukocyte function. Curr Opin Hematol,v.11, n.1, p.15-24, 2004.

FERREIRA, S.H.; NG, K.K.; VANE, J.R. The continuous bioassay of the release and disappearance of histamine in the circulation. $\mathrm{Br} J$ Pharmacol, v.49, n.3, p.543-553, 1973.

FORSBERG, M.; DRUID, P.; ZHENG, L.; STENDAHL, O.; SÄRNDAHL, E. Activation of Rac2 and $\mathrm{Cdc} 42$ on $\mathrm{Fc}$ and complement receptor ligation in human neutrophils. J Leukoc Biol, v.74, p.611-619, 2003.

FRAENKEL-CONRAT, H.; SINGER, B. Fractionation and composition of crotoxin. Arch Biochem Biophys, v.60, n.1, 1956.

GAKIDIS, M.A.; CULLERE, X.; OLSON, T.; WILSBACHER, J.L.; ZHANG, B.; MOORES, S.L.; LEY, K.; SWAT, W.; MAYADAS, T.; BRUGGE, J.S. Vav GEFs are required for beta2 integrin-dependent functions of neutrophils. J Cell Biol, v.166, n.2, p.273-282, 2004.

GANZ, T.; SELSTED, M.E.; SZKLAREK, D.; HARWIG, S.S.; DAHER, K.; BAINTON, D.F.; LEHER, R.I. Defensins. Natural peptide antibiotics of human neutrophils. J Clin Invest, v.76, p.1427-1435, 1985.

GILL, C.D.; COOPER, D.; ROSIGNOLI, M.; PERRETTI, M.; OLIANI, S.M. Inflammation-induced modulation of cellular galectin-1 and -3 expression in a model of rat peritonitis. Inflammation Research, v.55, n.3, p.99-107, 2006.

GODSON, C.; MITCHELL, S.; HARVEY, K.; PETASIS, N.; HOGG，N.; BRADY, H. Cutting edge: lipoxins rapidly stimulate nonphlogistic phagocytosis of apoptotic neutrophils by monocyte-derived macrophages. J Immunol, v.164, n.4, p.1663-1667, 2000. 
GOMES, R.T.; CAMARGO, R.P.F.; VIOTTI, A.P.; TAVARES, A.P.; REVELO, M.P.; FREITAS, T.V. Comparison of the biodistribution of free or liposomeentrapped Crotalus durissus terrificus (South Amarican rattlesnake) venom in mice. Comp Biochem Physiol C Toxicol Pharmacol, v.131, n.3, p.295-301, 2002.

GOPALAKRISHNAKONE，P.; DEMPSSTER， D.W.; HAWGOOD， B.J.; ELDER, H.Y. Cellular and mitochondrial changes induced in the structure of murine skeletal muscle by crotoxin, a neurotoxic phospholipase $\mathrm{A}_{2}$. Toxicon, v.22, n.1, p.85-98, 1984.

GROVES, E.; DART, A.E.; COVARELLI, V.; CARON, E. Molecular mechanisms of phagocytic uptake in mammalian cells. Cell Mol Life Sci, v.65, p.19571976, 2008.

HABERMANN, E.; BREITHAUPT, H. The crotoxin complex - an example of biochemical and pharmacological protein complementation. Toxicon, v.16, n.1, p.19-30, 1978.

HAWGOOD, B.J.; SANTANA DE SÁ, S. Changes in spontaneous and evoked release of transmitter induced by the crotoxin complex and this component phospholipase A2 at the frog neuromuscular junction. Neuroscience, v.4, n.2, p.293303, 1979.

IMLAY, J.A.; LINN, S. Bimodal parttern of killing of DNA-repair-defective or anoxically grown Escherichia coli by hydrogen peroxide. J Bacteriol, v.166, n.2, p.519$527,1986$.

IOVINE, N.M.; ELSBACH, P.; WEISS, J. An opsonic function of the neutrophil bactericidal/permeabilitty-increasing protein depends on both its $\mathrm{N}$ - and C-terminal domains. Proc Natl Acad Sci USA, v.94, p.10973-10978, 1997.

ISHIBASHI, Y.; YAMASHITA, T. Effects of a phagocytosis-stimulating factor derived from polymorphonuclear neutrophils on the functions of macrophages. Infect Immum, v.55, n.8, p.1762-1766, 1982. 
JANEWAY, C.A.; TRAVERS, P. The immune system in trealth and disease. In: Immunobiology. New York, Ed. Current Biology, Garland Publishing, p.12-16, 1994.

JORGE, M.T.; RIBEIRO, L.A. Epidemiologia e quadro clínico do acidente por cascavel Sul-Americana (Crotalus durissus). Rev Inst Med Trop São Paulo, v.34, n.4, p.374-354, 1992.

KIM, C.; DINAUER, M.C. Rac2 is essential regulator of neutrophil nicotinamide adenine dinucleotide phosphate oxidase activation in response to specific signaling pathways. J Immunol, v.166, n.2, p.1223-1232, 2001.

KIM, J.S.; DIEBOLDS, B.A.; KIM, J.I.; KIM, J.; LEE, J.Y. Rho is involved in superoxide formation during phagocytosis of opsonized zymosans. J Biol Chem, v.279, n.20, p.21589-21597, 2004.

KLEBANOFF, S.J. Myeloperoxidase: friend and foe. J Leukoc Biol, v.77, n.5, p.598-625, 2005.

KOBAYASHI, S.D.; VOYICH, Y.M.; DELEO, F.R. Regulation of the neutrophil-mediated inflammatory response to infection. Microbes Infect, v.5, n.14, p.1337-1344, 2003.

KOH,, A.L.Y.; SUN, C.X.; ZHU, F.; GLOGAUER, M. The role of Rac1 and Rac2 in bacterial killing. Cell Immunol, v.235, n.2, p.92-97, 2005.

KÖLSCH, V.; CHAREST, P.G., FIRTEL, R.A. The regulation of cell mobility and chemotaxis by phospholipid signaling. J Cell Sci, v.121, p.551-559, 2008.

KOWAL-VERN, A.; WLANGA, J.M.; SHAPR-PUCCI, M.; HOPPENSTEADT, D.; GAMELLI, R.L. Postburn edema and related changes in interleukin-2, leukocytes, platelet activation, endothelial-1, and C1 esterase inhibitor. $J$. Burn Care Rehabil, v.18, n.2, p.99-103, 1997.

KUMAR, V.; ABBAS, A.K.; FAUSTO, N. Inflamação aguda e crônica. In: Robbins \& Cotran - Patologia. São Paulo, Editora Elsevier, 7ª edição, p.49-89, 2005. 
KWIATKOWSKA, K.; SOBOTA, A. Signaling pathways in phagocytosis. Bioessays, v.21, n.5, p.422-431, 1999.

LANDUCCI, E.C.T.; ANTUNES, E.; DONATO, J.L.; FARO, R.; HYSLOP, S.; MARANGONI, S.; OLIVEIRA, B.; CIRINO, G.; DE NUCCI, G. Inhibition of carrageenan-induced rat paw edema by crotapotin, a polypeptide complexed with phospholipase A2. Br. J. Pharmacol., v.114, n.3, p.578-583, 1995.

LASZLO, J.; RUNDLES, R.W. Morphology of granulocytes. In: WILLIAMS, W.J.; BEUTLER, E.; ERSLEV, A.J.; RUNDLES. Hematology, Blakiston, p.560-567, 1972.

LE CABEC, V.; CARRÉNO, S.; MOISAND, A.; BORDIER, C.; MARIDONNEAU-PARINI, I. Complement receptor 3 (CD11b/CD18) mediates type I anda type II phagocytosis during nonopsonic and opsonic phagocytosis, respectively. $J$ Immunol, v.169, n.4, p.2003-2009, 2002.

LEE, W.L.; HARRISON, R.E.; GRINSTEIN, S. Phagocytosis by neutrophils. Microbes Infection, v.5, n.14, p.1299-1306, 2003.

LEHER, R.I.; GANZ, T.; SLKLAREK, D.; SELSTED, M.E. Modulation of the in vitro candidacidal activity of human neutrophil defensins by target cell metabolism and divalent cations. J Clin Invest, v.81, p.1829-1835, 1988.

LEVY, B.D.; ROMAN, M.; CHAPMAN, H.A.; RELLY, J.J.; DRAZEN, J.; SERHAN, C.N. Human alveolar macrophages have 15-lipoxygenase and generate 15(S)-hydroxy-5,8,11-cis-13-trans-eicosatetraenoic acid and lipoxins. J Clin Invest, v.92, n.3, p.1572-1579, 1993.

LEWIS, R.A.; AUSTEN, K.F. Leucotrienes and other products of the 5lipoxigenase pathway. Biochemistry and relation to pathobiology in human diseases. $N$ Engl J Med, v.323, o.645-655, 1990.

LIMA, T.S.; NUNES, F.P.; SAMPAIO, S.C.; SOUSA-E-SILVA, M.C.C. Efeito do veneno de Crotalus durissus terrificus sobre a fagocitose por neutrófilos no modelo 
de peritonite. In: $39^{\circ}$ Congresso Brasileiro de Farmacologia e Terapêutica Experimental, Ribeirão Preto, 2007.

MADERNA, P.; GODSON, C. Lipoxins: resolutionary road. Br J Pharmacol, v.158, n.4, p.947-959, 2009.

MAGALHÃES, R.A.; RIBEIRO, M.M.F., REZENDE, N.A.; AMARAL, C.F.S. Rabdomiólise secundária a acidente ofídico crotálico (Crotalus durissus terrificus). Rev Inst Méd Trop São Paulo, v.28, n.4, p.228-233, 1986.

MAJNO, G.; JORIS, I. Inflammation: The actors and their language. In: Cells, tissues and disease. Principles of general pathology. New York, Oxford University Press, p.307-382, 2004.

MALECH, H.L.; GALLIN, J.I. Current concepts: immunology. Neutrophils in human diseases. N. England J Med, v.317, n. 11, p.687-694, 1987.

MANIAK, M.; RAUCHENBERGER, R.; ALBRECHT, R.; MURPHY, J.; GERISCH, G. Coronin involved in phagocytosis: Dynamics of particle-induced relocalization visualized by a green fluorescent protein Tag. Cell, v.83, p.915-924, 1995.

MASSOL, P.; MONTCOURRIERP.; GUILLEMONT, J.C.; CHAVRIER, P. Fcreceptor-mediated phagocytosis requires CDC42 and Rac1. Embo J, v.17, n.21, p.62196229, 1998.

MAY, R.C.; CARON, E.; HALL, A.; MACHESKY, L.M. Involvement of the Arp2/3 complex in phagocytosis mediated by Fc $\gamma \mathrm{R}$ or CR3. Nat Cell Biol, v.2, n.4, 2000 .

MELGAREJO, A.R. Serpentes peçonhentas do Brasil. In: CARDOSO, J.L.C.; FRANÇA, F.O.S.; WEN, J.H.; MÁLAQUE, C.M.S.; HADDAD JR., V. Acidentes peçonhentos no Brasil - biologia, clínica e terapêutica dos acidentes. São Paulo, Editora Sarvier, p.33-61, 2003.

METCALF, D. Haematopoietic growth factors 1. Lancet, v.1, n.8642, p.825$827,1989$. 
MINAKAMI, R.; MAEHARA, Y.; KAMAKURA, S.; KUMANO, O.; MIYANO, K.; SUMIMOTO, H. Membrane phospholipid metabolism during phagocytosis in human neutrophils. Genes Cells, v.15, n.5, 409-424, 2010.

MOLLINEDO, F.; GAJATE, C.; SCHNEIDER, D.L. Cytochrome b cofractionates with gelatinase-containg granules in human neutrophils. Mol Cell Biochem, v.105, n.1, p.49-60, 1991.

MOURA-GONÇALVES, J.; VIEIRA, A. Estudo sobre veneno de serpentes brasileiras. I. Análise Eletroforética. An Acad Bras Cienci, v.22, p.141-150, 1950.

NAHAS, L.; MACFARLANE, R.G.; DENSON, K.W. A study of the coagulant action of eight snake venons. Thromb Diath Haemorrh, v.12, p.355-367, 1964.

NEUMAN, E.; HULEATT, J.W.; JACK, R.M. Granulocyte-Macrophage colony-stimulating factor increased synthesis and expression of CR1 and CR3 by human peripheral blood neutrophils. J Immunol, v.145, n.10, p.3325-3332, 1990.

NIGGLI, V. Signaling to migration in neutrophils: importance of localized pathways. Int J Biochem Cell Biol, v.35, n.12, p.1619-1638, 2003.

NUNES, F.P.; SAMPAIO, S.C.; SANTORO, M.L.; SOUSA-SILVA, M.C. Long-lasting anti-inflammatory properties of Crotalus durissus terrificus snake venom in mice. Toxicon, v.49, n.8, p.1090-8, 2007.

NUNES, F.P.; ZYCHAR, B.C.; DELLA-CASA, M.S.; SAMPAIO, S.C.; GONÇALVEZ, L.R.; CIRILLO, M.C. Crotoxin is responsible for the long-lasting antiinflammatory effect os Crotalus durissus terrificus snake venom: involvement of formyl peptide receptors. Toxicon, v.55, n.6, p.1100-6, 2010.

PICK, E., KEISARI, Y. A simple colorimetric method for the measurement of hydrogen peroxide produced by cells in culture. J Immunol Methods, v.38, n.1-2, p.16170,1980 .

PICK, E.; MIZEL, D. Rapid microassays for the measurement of superoxide and hydrogen peroxide production by macrophages in culture using na automatic enzyme immunoassay reader. J Immunol Methods, v.46, n.2, p.211-26, 1981. 
OWNBY, L.C.; CAMERON, D.; TU, A.T. Isolation of myotoxic component from rattlesnake (Crotalus viridis viridis) venom. Am J Pathol, v.85, n.1, p.149-166, 1976.

PRADO-FRANCESCHI, J.; BRAZIL, O.V. Convulxin, a new toxin from the venom of the South Amerizan rattlesnake Crotalus durissus terrificus. Toxicon, v.19, n.6, p.875-887, 1981.

RANGEL-SANTOS, A.; LIMA, C.; LOPES-FERREIRA, M.; CARDOSO, D.F. Immunosuppresive role of principal toxin (crotoxin) of Crotalus durissus terrificus venom. Toxicon, v.44, n.6, p.609-616, 2004.

RANKIN, J. Biological mediators of acute inflammation. AACN Clinical Issues, v.15, n.1, 3-17, 2004.

RIVAS-FUENTES, S.; GARCÍA-GARCÍA, E.; NIETO-CASTANEDA, G.; ROSALES, C. Fcgamma receptors exhibit different phagocytosis potential in human neutrophils. Cell Immunol, v.263, n.1, p.114-121, 2010.

ROCHA e SILVA, M.; GARCIA-LEME, J. Chemical mediators of the acute inflammatory reaction. Oxford: Pergamon Press, p.1-47, 1972.

ROOS, D.; VAN BRUGGEN, R.; MEISCHL, C. Oxidative killing of microbes by neutrophils. Microbes Infect,v.5, n.14, p.1307-1315, 2003.

ROSENFELD, G. Método rápido de coloração de esfregaços de sangue. Noções práticas sobre corantes pancrômicos e estudos de diversos fatores. Mem Inst Butantan, v.20, p.315-28, 1947.

ROSENFELD, G. Symptomathology, pathology and treatment of snakes bites in South America. In: BÜRCHEL, W; BUCKLEY, E. Venomous animals and their venoms. New York, Academic Press, p.345-384, 1971.

RYAN, A.; GODSON, C. Lipoxins: regulators of resolution. Curr Opin Pharmacol, v.10, n.2, p.166-172, 2010.

SAMPAIO, S.C.; SOUSA-E-SILVA, M.C.C.; BORELLI, P., CURI, R., CURY, 
Y. Crotalus durissus terrificus snake venom regulates macrophage metabolism and function. J Leukoc Biol, v.70, n.4, p.551-58, 2001.

SAMPAIO, S.C.; BRIGATTE, P.; SOUSA-E-SILVA, M.C.C.; DOS-SANTOS, E.C.; RANGEL-SANTOS, A.C.; CURI, R.; CURY, Y. Contribution of crotoxin for the inhibitory effect of Crotalus durissus terrificus snake venom on macrophage function. Toxicon, v.41, n.7, p.899-07, 2003.

SAMPAIO, S.C.; RANGEL-SANTOS, A.C.; PERES C.M.; CURI, R.; CURY, Y. Inhibitory effect of phospholipase $\mathrm{A}_{2}$ isolated from Crotalus durissus terrificus venom on macrophage function. Toxicon, v.45, p.671-676, 2005.

SAMPAIO, S.C; ALBA-LOUREIRO, T.C.; BRIGATTE, P.; LANDGRAF, R.G.; DOS SANTOS, E.C.; CURI, R.; CURY, Y. Lipoxygenase-derived eicosanoids are involved in the inhibitory effect of Crotalus durissus terrificus venom or crotoxin on rat macrophage phagocytosis. Toxicon, v.47, n.3, p.313-321, 2006a.

SAMPAIO, S.C.; SANTOS, M.F.; COSTA, E.P.; RANGEL-SANTOS, A.C.; CARNEIRO, S.M.; CURI, R.; CURY, Y. Crotoxin induces actin reorganization and inhibits tyrosine phosphorylation and activity of small GTPases in rat macrophages. Toxicon, v.47, n.8, p.909-919, 2006b.

SAMPAIO, S.C.; HYSLOP, S.; FONTES, M.R.M.; PRADO-FRANCESCHI, J.; ZAMBELli, V.O.; MAGRO, A.J.; BRIGATTE, P.; GUTIERREZ, V.P.; CURY, Y. Crotoxin: Novel activities for a classic $\beta$-neurotoxin. Toxicon, v.55, p.1045-1060, 2010.

SANO-MARTINS, I.S.; TOMY, S.C.; CAMPOLINA, D.; DIAS, M.B.; DE CASTRO, S.C.B.; SOUSA-E-SILVA, M.C.C.; AMARAL, C.F.S.; REZENDE, M.A.; KAMIGUTI, A.S.; WARRELL, D.A.; THEAKSTON, R.D.G. Coagulopathy following lethal and non-lethal envenoming of humans by the South American rattlesnake in Brazil. $Q J M$, v.94, n.10, p.551-559, 2001.

SCHMITZ, A.A.P.; GOVEK, E.E.; BÖTTNER, B.; VAN AELST, L. Rho GTPases: Signaling, Migration and Invasion. Exp Cell Res,v.261, n.1, p.1-12, 2000. 
SCHYMEINSKY, J.; MÓCSAI, A.; WALZOG, B. Neutrophil activation via $\beta_{2}$ integrins (CD11/CD18): Molecular mechanisms and clinical implications. Thromb Haemost, v.98, p.262-273, 2007.

SERHAN, C.N. SHEPPARD, K.A. Lipoxin formation during human neutrophilplatelet interactions. Evidence for the transformation of leukotriene $\mathrm{A}_{4}$ by platelet 12lipoxigenase in vitro. J Clinc Invest, v.85, n.3, p.772-780, 1990.

SHI, Y.; TOHYAMA, Y.; KADONO, T.; HE, J.; MIAH, S.M.S.; HAZAMA, R.; TANAKA, C. Protein-tyrosine kinase Syk is required for pathogen engulfment in complement-mediated phagocytosis. Blood, v.107, n.11, p.4554-4562, 2006.

SILVA, M.T. When two is better than one: macrophages and neutrophils work in concert in innate immunity as complementary and cooperative partners of a myeloid phagocyte system. J. Leukoc Biol, v.87, n.1, 2010.

SIMON, S.I.; GREEN, C.E. Molecular mechanics and dynamics of leukocyte recruitment during inflammation. Annu Rev Biomed Eng, v.7, p.151-185, 2005.

SINAN. Sistema de Informação de Agravos de Notificação. Ministério da Saúde. www.saude.gov.br/sinanweb/. Acesso em novembro de 2010, dados de 2008.

SOUSA-E-SILVA, M.C.C.; GONÇALVES, L.R.C.; MARIANO, M. The venom of South American rattlesnakes inhibits macrophage functions and is endowed with anti-inflammatory properties. Mediators Inflamm, v.5, p.18-23, 1996.

SOUSA-E-SILVA, M.C.C.; TOMY, S.C.; TAVARES, F.L.; NAVAJAS, L.C.; LARSSON, M.H.M.A.; LUCAS, S.R.R.; KOGIKA, M.M.; SANO-MARTINS, I. S. Hematological, hemostatic and clinical chemistry disturbances induced by Crotalus durissus terrificus snake venom in dogs. Hum Exp Toxicol, v.22, n.9, p.491-500, 2003.

SLOTTA, K.H.; FRAENKEL-CONRAT, H. Estudos químicos sobre os venenos ofídicos. Purificação e cristalização do veneno da cobra cascavel. Mem Inst Butantan, v.12, p.505-512, 1938.

SPRINGER, T.A. Traffic signals on endothelium for lymphocyte recirculation and leukocyte emigration. Annu Rev Physiol, v.57, p.827-872, 1995. 
TAPON, N.; HALL, A. Rho, Rac and Ccd42 GTPases regulate the organization of the actin cytoskeleton. Curr Opin Cell Biol, v.9, n.1, p.86-92, 1997.

TEDGUI, A.; MALLAT, Z. Anti-inflammatory mechanisms in the vascular wall. Circ Res, v.88, p.877-887, 2001.

UNKELESS, J.C.; WRIGHT, S.D. Phagocytic cells: Fcy and complement receptors. In: GALLIN, J.I.; GOLDSTEIN, I.M.; SNYDERMAN, R. Inflammation: basic principles and clinical correlates. New York, Raven Press, p.343, 1988.

VANE, J.R. The endothelium: maestro of the blood circulation. Philos Trans $R$ Soc Lond B Biol Sci., v.343, n.1304, p.225-246, 1994.

VINEGAR, R.; TRUAX, J.F.; SELPH, J.L.; VOELKER, F.A. Pathway on onset, development and decay of carrageenan pleurisy in the rat. Fred Proc, v.41, n.9, p.2588$2595,1982$.

VITAL-BRAZIL, O.; EXCELL, B.J. Action of crotoxin and crotactin from the venom of Crotalus durissus terrificus (South American rattlesnake) on the frog neuromuscular junction. J Physiol, v.212, n.2, p.34-35, 1971.

VITAL-BRAZIL, O. Neurotoxins from South American rattlesnake. J Formosan Med Assoc, v.71, p.394-396, 1972.

WALZOG, B.; OFFERMANNS, S.; ZAKRZEWICS, A.; GAEHTGENS, P.; LEY, K. $\beta 2$ integrins mediate protein tyrosine phosphorilation in human neutrophils. $J$ Leokoc Biol, v.59, n.5, p.747-753, 1996.

WERNER, E. GTPases and reactive oxygen species: switches for killing and signaling. J Cell Sci, v.117, p.143-153, 2004.

WINTERBOURN, C.C.; Hampton, B.M.; Livesey, H.J.; Kettle, J.A.. Modeling the Reactions of Superoxide and Myeloperoxidase in the Neutrophil Phagosome. J Biol Chem, v.281, n.52, p.39860-39869, 2006. 
ZIGMOND, S.H.; HIRSCH. J.G. Effects of cytochalasin B on polymorphonuclear leucocyte locomotion, phagocytosis and glycolysis. Exp Cell Res, v.73, p.383-393, 1972. 